\title{
Investors' expectations around quantitative easing: does liquidity injection affect European banks equally?
}

\author{
Sara Longo ${ }^{1}$ (D) $\cdot$ Antonio Parbonetti ${ }^{2} \cdot$ Amedeo Pugliese $^{2,3}$
}

Accepted: 26 April 2021 / Published online: 12 May 2021

(c) The Author(s) 2021

\begin{abstract}
The role of liquidity in the banking industry is increasingly under the spotlight since the Global Financial Crisis (GFC) in 2007. Prior evidence offers contrasting findings on the role played by liquidity in banks: whilst it ensures systemic financial stability, at the same time it raises agency costs. Notwithstanding this, European banks benefited from a generous liquidity injection following the launch of the Quantitative Easing (QE) programme by the European Central Bank (ECB) in 2015-2016. We leverage on the release of the $\mathrm{QE}$ and investigate whether investors' reactions to the announcements of new liquidity injections vary according to bank-level characteristics of the European banks: namely, their financial soundness, asset portfolio quality and the level of transparency. Our findings document an overall negative market reaction to the QE announcements; at a more fine-grained level of analysis we highlight that banks falling short of the regulatory requirements are not expected to benefit from additional liquidity. This study contributes to the literature on the role of liquidity in banks by showing important boundary conditions to the beneficial role of liquidity in banks, that is-because of the regulatory capital requirements-liquidity is only valuable to investors if it can be reinvested once constraints are overcome.
\end{abstract}

Keywords Capital markets · Liquidity injection · Quantitative easing · European banks $\cdot$ Bank characteristics

Sara Longo

sara.longo@unibz.it

1 Faculty of Economics and Management, Free University of Bolzano, Bolzano, Italy

2 Department of Economics and Management, University of Padova, Padua, Italy

3 Universitat Pompeu Fabra, Barcelona, Spain 


\section{Introduction}

The role of liquidity in the banking industry attracts substantial attention of both regulators and researchers, especially since the financial crisis in 2007-2009. This is underscored by several instances in which banks' compliance with regulatory requirements in terms of capital ratios, liquidity shortage or maturity mismatch had dire consequences on the banking system (Calomiris et al., 2015). The ensuing Basel III Framework emphasizes the importance of liquidity through the requirement of a 'liquidity coverage ratio' (LCR) that should shield banks and the financial systems from market frictions and breakdowns (Acharya \& Ryan, 2016). Whilst liquidity contributes - alongside with capital requirements - to safeguard a bank's financial viability and transmission mechanism to the market (Calomiris \& Khan, 2015), it may inadvertently enhance managerial discretion in terms of investment decisions and executive compensation: a typical agency problem (Flannery, 1994; Jensen \& Meckling, 1976; Myers \& Rajan, 1998). In fact, the 'free cash flow' dilemma (hereafter FCF) posits that managers frequently inspect cash holdings as free cash flows and oftentimes abuse them for individual advantages.

This study aims at exploring whether the announcement of liquidity injection affects bank valuation (proxied by stock market reaction). The role of liquidity in the banking industry has been vastly investigated, and a wealth of studies provide conflicting empirical evidences as to whether it exerts positive or negative effects of banks' valuation. On the one hand, holding liquidity is costly, as liquidity buffers may prompt managerial moral hazard if a bank becomes insolvent (Myers \& Rajan, $1998 \mathrm{~F}^{1}$ ). This implies that banks should maintain liquid reserves to service demand deposits so that they have a comparative advantage in making illiquid loans. On the other hand, bankers use liquidity incentivized to take on excess risk and leverage for satisfying compensation's needs based on personal benefits (Acharya \& Ryan, 2016; Bushman \& Williams, 2012). Paradoxically, liquidity issues may arise as a result of the stringent regulatory requirements: during difficult times, managers prefer holding cash tight (vis a vis investing them) to meet capital adequacy requirements and avoid increasing their credit risk - the undesirable outcome is a reduction in lending activity. For these reasons, whether liquidity is beneficial or not is an open, empirical issue.

A significant body of research examines liquidity from a regulatory perspective, especially in relation to the optimal level of liquidity for banks (Cifuentes et al., 2005). The literature shares consensus in terms of conditioning this level on bank size, capital structure and transparency. Large banks benefit from economies of scale (Boyd \& Heitz, 2016) in screening and monitoring borrowers and from great diversification. Because of their "too-big-to-fail" position, large banks might hold less capital in excess of regulatory requirements (Gropp \& Heider, 2010). Alternatively, large banks could create more liquidity than small banks because they have easier access to the lender of last resort and because they would be the first to benefit

\footnotetext{
${ }^{1}$ Myers and Rajan (1998).
} 
from safety net (Distinguin et al., 2013). Furthermore, well-capitalized banks are perceived as "less risky" by depositors and investors (Khan, 2019), whereas lack of capital adequacy triggers (1) a reduction of bank lending (increase of borrowing costs and decrease of credit availability), (2) a deleveraging through fire sales and (3) an increase of risk-shifting incentives (Bushman \& Williams, 2015). Other theoretical arguments highlight the role played by liquidity in the agency relation, where liquidity provides a managerial discretion and misalignment with shareholders' interests.

We exploit the features of the Quantitative Easing program (hereafter QE) launched by the European Central Bank (ECB) as an instrument to address the following questions: first, do investors react to the announcements of new liquidity for the Euro banking system and, second, do bank characteristics shape the investors' assessments of bank valuation in the aftermath of the announcements?

The QE offers a unique opportunity to address these questions, because: (1) liquidity is channeled to banks on the base of eligible assets chosen a priori by the European Central Bank; (2) the amount of liquidity and the timing in which banks receive new liquidity were unknown and hard to predict; (3) liquidity for banks is the output of a mechanism with no bankers' efforts and strategies. All these factors are somewhat exogenous to the otherwise (endogenously) chosen level of liquidity. To test our hypotheses, we use a sample of 120 European listed banks in the period surrounding the announcements of the QE (2015-2016). Most institutions included in the sample are commercial banks whose main feature is the lack of a deposit insurance like in US, exposing them to a potential default. We conduct an event study following the Fama-French three factor model to estimate the cumulative abnormal returns (CARs) as a proxy for investors' assessment of the valuation of banks. We argue that these changes may accrue to banks as a reflection of (un)expected additional liquidity. Finally, we exploit the cross-sectional variation in stock market's response as explained by three key bank-level attributes (e.g., capital adequacy, asset quality and risk exposure).

Our analyses reveal interesting results and patterns in terms of why and when liquidity matters. First, we find a negative reaction to the QE announcements of additional liquidity among the European banks involved: this is consistent across all events and seems to suggest that investors do not foresee banks would gain benefits out of the upcoming provisions of liquidity. Next, the results stemming from the cross-sectional analyses at bank-level reveal that the expectations of new liquidity positively affect strongly capitalized banks, whereas those not fulfilling all the requirements and expectations, seem to be unaffected.

Our study complements extant literature in three important aspects. First, we examined the expected benefits of additional, exogenous liquidity on a sample of European banks presenting elements of homogeneity because of the same accounting and banking regulation and the same supervision exercised by the ECB, and heterogeneity in terms of different capital management choices reflected in different assets composition. Second, while other studies consider legal, extra-legal, informal and political factors to investigate the earnings management in the banking industry (Fonseca \& Gonzalez, 2008; Dal Maso et al., 2018; Kanagaretnam et al., 2011, 2014a, 2014b), our focus is to see how the investors' response to new liquidity is 
shaped by specific bank characteristics as (1) the capital adequacy; (2) the asset quality and (3) the risk exposure. These attributes are also known as the primary tools used for the banking supervision (ECB) during the transparency exercises and further stress tests. Third, we analyze a time period between 2014 and 2016, when after a long period of credit crunch all European banks had the chance to regain investors' trust and to replenish their financial statements thanks to the QE intervention.

Finally, our study contributes to appreciating the role of liquidity provision arguing that the effects of liquidity are not uniform albeit conditional on a series of banklevel features. While theory suggests a directional relationship from capital to liquidity, where well-capitalized banks behave differently assuming more risk and able to diversely manage their liquidity (Diamond \& Rajan, 2000, 2001), our findings suggest that the well-capitalized banks would increase their capital adequacy, but not their risk exposure, because the combination of new liquidity provided by the ECB and higher levels of regulatory capital allows banks to be stronger and more stable from an investor's perspective (Distinguin et al., 2013).

The remainder of the paper is organized as follows. Section "Literature review and hypotheses development" reviews the extant theoretical and empirical literature on the role played by liquidity in the banking industry and develops hypotheses. Section "Empirical design" describes the empirical design (sample and methodology). Section "Results" provides the main empirical findings and describes further additional tests. Finally, Sect. "Conclusion" concludes and discusses some implications and limitations of our study.

\section{Literature review and hypotheses development}

To derive our theoretical predictions on the effects of liquidity on investors' assessment of bank value, we build on two strands of literature combining theoretical arguments and empirical evidences related to the liquidity regulation, with studies specifically focusing on the relation between liquidity provisions and bank valuation. Following each of these two subsections, we develop two hypotheses regarding the relation between investors' response and bank attributes to understand if provisions of new liquidity is equally beneficial for all banks.

\subsection{Liquidity and bank valuation}

The way in which the regulator identifies and suggests optimal bank liquidity buffers is thorough mechanical quantitative requirements (Cifuentes et al., 2005). Barth et al. (2008) document the importance of "rethinking regulation" and highlight that liquidity in the banking industry ensures a proper asset allocation and a regular lending activity. Nevertheless, Glaeser and Shleifer (2001) show that liquidity is costly, because it may be difficult to define the set of appropriate liquid assets.

It is well known that illiquidity triggers bankruptcies and implies negative externalities (Dewatripont and Tirole, 1993) with a relevant contagion-risk on the entire banking system and a systemic-risk on the entire economic system (Allen \& 
Carletti, 2008; Khan, 2019). In the aftermath of the last financial crisis (2007-2009), the regulator reacts to liquidity threats outlining a new ratio, the liquidity coverage ratio (LCR), dedicated to maintaining a reasonable level of liquidity and properly managing risks (Basel III framework). The financial crisis highlights that despite the substantial alignments to the regulatory capital ratios, banks face higher likelihood of default because of a low level of liquid assets (Calomiris et al., 2015). The efforts raised from the international endorsement of Basel III address that only banks with enough capital, liquid assets and stable funding structures can more effectively maintain their intermediation capacity amid external negative shocks (Haan and van den End, 2013; Kim \& Sohn, 2017).

Liquidity is shaped by bank size, capital structure and transparency, therefore we see that large banks benefit from economies of scale (Boyd \& Heitz, 2016) in screening and monitoring borrowers and from great diversification. Beyond their "too-big-to-fail" position, large banks might hold less capital in excess of regulatory requirements (Gropp \& Heider, 2010). Alternatively, large banks could create more liquidity than small banks because they have easier access to the lender of last resort and because they would be the first to benefit from a safety net; (Ratnovski, 2009). Furthermore, well-capitalized banks are perceived as "less risky" by depositors and investors (Khan, 2019), when the lack of capital adequacy triggers (1) a reduction of bank lending (increase of borrowing costs and decrease of credit availability), (2) a deleveraging through fire sales and (3) an increase of risk-shifting incentives (Bushman \& Williams, 2015). Some prior studies focus on samples of banks split on several levels of regulatory capital (Bowen \& Khan, 2014; Khan, 2019), where they define well-capitalized banks as those that are supposed to have sufficient capital to serve as a buffer from market swings, strengthening the concept of well capitalized banks as "strongly capitalized", and not-well capitalized banks as "poorly capitalized". Moreover, bank liquidity is strongly connected with risk management activities and tools, in the way that a proper liquidity management affects positively bank investments and lending activity (Kim \& Sohn, 2017). Theoretical conjectures propose a high connection between liquidity risk and credit risk, mainly addressed by funding and lending channels. However, empirical evidences show that there is no reliable relation between the two risks, but both influence the probability of default for a bank (Imbierowicz \& Rauch, 2014). While liquidity risk is the output of bank solvency, liquidity ratios required by the Basel Committee reflect immediately the access of refinancing in a transparent way (Ratnovski, 2013).

Agency theory takes a different stance on the role of liquidity (Flannery, 1994; Jensen \& Meckling, 1976; Myers \& Rajan, 1998) as it allows a managerial discretion in terms of investment decisions and executive compensation structure. Recent literature emphasizes aspects related to the risk-adjustments given the new liquidity provisions. For instance, Haan and Van den End (2013) study liquidity hoarding so called "predatory behaviour" aimed at the exploitation of urgent funding needs of other market participants. They show that banks with surplus liquidity have an incentive to strategically underutilize liquidity and provide it to other banks to be able to benefit from the latter's forced fire sales of assets against low liquidation prices. Furthermore, Diamond and Rajan (2012) show that the expectation of distressed banks being forced to sell assets in the future at fire-sale prices drives 
healthy banks to hoard liquid funds so as to allow them to take advantage of future investment opportunities.

In spite of a generalized agreement around the idea that market liquidity and funding liquidity are mutually reinforcing leading to dangerous liquidity spirals (Brunnermeier \& Pedersen, 2009), the free cash flow dilemma implies a further problem: managers may be tempted to withhold excess cash and either (i) refrain from using it to pursue value creating projects, or (ii) use them at their individual advantages. Particularly, in the banking industry, holding liquidity is costly because of facilitating managerial moral hazard if a bank becomes insolvent (Myers \& Rajan, 1998). In addition, bankers are incentivized to assume more risks for increasing the level of personal benefits from a compensation`s perspective (Bushman \& Williams, 2012; Acharya \& Ryan, 2016; Chen et al., 2017). Finally, the paradoxical issue is that a free-cash-flow problem can be enhanced by the same regulation since bankers prefer holding cash when capital adequacy concerns and credit risk increase by reducing lending activity (DeAngelo \& Stulz, 2015).

In sum, we are not able to offer a directional prediction as to whether markets react positively or negatively to new liquidity provisions for European banks, thus we derive the following hypothesis:

H1 Announcements of QE liquidity injection are associated with abnormal returns in share prices of EU banks.

\subsection{Bank characteristics, liquidity and bank valuation}

Liquidity represents the engine of banks' core business to support real economic growth (Berger \& Sedunov, 2017), because it is essential to banks in order to ensure future lending activity to render their capital structure more robust (Gropper and Heider, 2010). Moreover, liquidity represents the primary source of its vulnerability facing the risk of depositors' claims in the short-term. In particular, liquidity is the output of a transformation process of the underlying loan and deposit contracts balancing illiquid loans with liquid deposits. Furthermore, liquidity transformation is connected with maturity transformation, where banks use short-term liabilities to finance longer-term assets.

If liquidity allows raising agency costs (Attig et al., 2013; Bushman et al., 2018; Busta et al., 2014; Flannery, 1994; Jensen \& Meckling, 1976; Myers \& Rajan, 1998), then liquid assets provide accessible ways to reinvest in other assets when prices are low and reduce same investing risks by ensuring that an investor will be able to quickly react to market moves (Brunnermeier and Yogo, 2009). The intrinsic liquidity production has been extensively discussed by, among others, Diamond and Dybvig (1983), Diamond \& Rajan (2001), Gorton \& Pennacchi (1990), Holmström \& Tirole (1998), Holmström \& Tirole (1998) and Gorton \& Winton (2017).

A bank's financial structure also matters (Kiyotaki \& Moore, 1997; Shleifer \& Vishny, 1992; Zingales, 2009); more capitalized banks are less exposed to monetary policy changes, because they are perceived safer by investors and because they have less leverage (Madura \& Schnusenberg, 2000). Furthermore, liquidity requirements 
can compromise banks' transparency choices and increase refinancing risk. Indeed, banks can choose the level of transparency (the amount of information available to outsiders), albeit higher transparency reduces the owner-manager's private benefit of control (Ratnovski, 2013). From a different standpoint, Lang \& Maffett (2011) show that transparency reduces firm-level liquidity uncertainty, while $\mathrm{Ng}$ (2011) shows that increased information quality can reduce a firm's exposure to systematic liquidity risk. These studies respectively suggest that accounting variables can affect firm valuation and cost-of-capital through their impact on different aspects of liquidity. Although some doubt may arise about the economic significance of such effects on average, further evidence from the recent financial crisis confirms the important role of accounting information during liquidity events (Sadka, 2011).

Nevertheless, how bank attributes affect bank valuation upon additional exogenous liquidity injections has not yet been fully explored (Ahrens et al., 2011). Banks with a high rate of liquid assets tend to adjust their capital ratio more quickly (Memmel \& Raupach, 2010). Banks usually operate above minimum regulatory capital requirements in order to minimise the probability of reaching the regulatory limit of solvency ratios (Laurent Maurin and Mervi Toivanen). In relation to the asset quality, the bank loan response to QE might differ depending on the liquidity position of a bank (Kashyap \& Stein, 2000). Focusing on the risk solvency ratios we know that before the adoption of QE, European banks increased their portfolios purchasing sovereign debt securities and consequently the sovereign default risk, once again corroborating in financial stability (Acharya \& Steffen, 2015). In addition, liquidity has the power to quickly adjust capital ratios, while it becomes a new source for reserves every time a bank provides further loan loss provisions for impaired loans. Given that liquidity vulnerability makes banks unstable, liquidity also plays a role in the valuation of financial assets that can be affected by different risk factors (Chen et al., 2017). Under the perspective of risks taken by a bank, we know that the QE program pointed out that a liquidity shock aims to purchase relatively "good assets", such as those considered safe and less risky assets with high ratings, leaving bad assets in banks' portfolios.

While other studies consider legal, extra-legal, informal and political factors to investigate the management of earnings in the banking industry (Fonseca \& Gonzalez, 2008; Kanagaretnam et al., 2011, 2014a, b; Dal Maso et al., 2018), we focus the attention on specific bank characteristics able to shape the investors' response to new liquidity injections. In particular, bank characteristics we consider are a bank's capital adequacy, asset quality and risk exposure. Likewise, we focus on well-capitalised banks perceived "less risky" by both depositors and investors arguing that capital inadequacy implies negative consequences in terms of (reduction of) lending activity as well as on low-risk banks, such as those banks with enough regulatory capital and liquid assets, able to offer a larger amount of credit.

In regard to exploit investors' response to the new liquidity injection provided by the Quantitative Easing program and on the base of the above theoretical and empirical evidences, we predict: (1) to find no relevant effects for those banks already meeting capital regulatory requirements; (2) to find positive effects of additional liquidity for those banks who could afford lending, however lacked the required liquid resources and deemed weakly capitalized. On the basis of the above reasoning, 
we develop a second hypothesis exploiting the different levels of capitalization across our sample of European banks:

H2 The magnitude of the stock price reaction to the announcements of QE liquidity injection affects EU banks differently according to their characteristics.

\section{Empirical design}

\subsection{Event study methodology}

In order to assess the market response to the new liquidity injection of the Quantitative Easing among European banks (hypothesis H1), we first conduct an event study adopting a Fama-French three factor model. This is consistent with prior works using event studies (Kothari and Werner 2007) focusing on the behaviour of firms' stock prices around corporate events and macroeconomic shocks (financial crisis, illiquidity, TARP). In a corporate context, event studies permit measuring the magnitude of abnormal performance at the time of an event and the impact of this type of event on wealth of the firms' claimholders. We see that if financial markets are informationally efficient, there should be an immediate reaction to the event on the announcement date and no further reaction on subsequent trading days (Brown \& Warner, 1985; Fama, 1991). Event studies are recurrent in accounting and finance domains and have been applied to a variety of firm specific and economy wide events (MacKinlay, 1997), especially in relation to the effects of earnings announcements on stock prices, which has received much attention around regulatory changes (Cornett et al., 2011; Gao et al., 2018; Khan et al., 2018) and around the adoption of conventional and unconventional monetary policies by a central bank (Fiordelisi et al., 2014; Ricci, 2015).

In detail, we adopt a Fama-French three factor model (Viale et al., 2009) and identify six events between 2015 and 2016, in relation to the initial launch of the QE programme for the Euro zone, which are expected to materially affect equity valuations of banks. Information about the announcements is gathered via the ECB website (e.g., "Public Sector Purchase Programme"). Each event corresponds to the day in which the ECB releases official information, features and further implementations about the QE taking effect in March 20151F. ${ }^{2}$ The aim of updates to the QE is due to the original rules rapidly constraining the purchases in countries with low levels of public debt and it raises the need to expand the "universe of available debt securities occurring to the supranational agencies" $2 F^{3}$. Specifically, "Appendix 1" reports a figure summarizing the timeline (Panel A), the methodology used to conduct the event study (Panel B-estimation period and event window computation) and finally the description of all the events (Panel C). Each announcement conveys

\footnotetext{
${ }^{2}$ https://www.ecb.europa.eu/mopo/implement/omt/html/index.en.html.

3 http://bruegel.org/2016/02/the-european-central-banks-quantitative-easing-programme-limits-andrisks/.
} 
varying information about QE programme. We see that the events present several informational features, which have been classified in three categories: (1) "information announcements" related to the process of purchases by ECB; (2) "details announcements", through which ECB describes the rules and the requirements of the QE programme; (3) "implementations announcements" following which ECB adds new elements related to its purchases of public sector assets, like new financial instruments issued by supranational agencies. In the meanwhile, ECB adds to the list of the eligible assets corporate bonds explicitly not held by European banks (i.e., bonds issued by big European companies), as well as an increase of the amount for the monthly purchases (from $€ 60$ to 80 billion) and finally an increase of the same duration of the programme (until the end of 2017) to allow still new liquidity injection. The aim of most changes related to the QE ongoing and functioning is because the original rules rapidly constrain the purchases in countries with low levels of public debt with the consequent raising need to expand the "universe of available debt securities occurring to the supranational agencies".

The event study methodology allows estimating the cumulative abnormal returns $(C A R s)$ as a proxy for the changes in investors' assessment of the future expected benefits of the European banks included in our sample around the total six events as well as for each event related to the QE. This represents a change in bank valuation that can be unequivocally attributed to the expected increases in liquid assets as a result of the exogenous QE. Before January 2015, we can see from the figure reported in "Appendix 3" that the QE program in the Euro zone was not "particularly" expected. Thanks to the results obtained through Google Trend, we can see that on the days prior to the first announcement there was a substantial increase of news and information about the possible decision to adopt the unconventional macroeconomic policy for the first time of the economic history of the Euro zone. However, we lack data about the exact amount and timing of the purchases of assets by the ECB because of the no disclosure of information about the timing and the amount of bonds relieved from the banks' portfolios during the QE.

We consider the daily stock price, the market value and the book value of equity for each listed bank and the daily price of the main financial market index (Stoxx Europe 600). For short events, we chose a window range of 3 days $(-1 ;+1)$ and 5 days $(-1 ;+3)$ or $(-2 ;+2)$ for the computation of cumulative abnormal returns $(C A R s)$. The estimation period is based on a range of twenty-five working days prior to announcement $(-30 ;-5)$, excluding the use of alternative and longer observation windows $(-60 ;-5)$. In our case, we do not have any overlapping dates within a given QE announcement or any of the events. With non-overlapping events in the whole period and after controlling for the presence of other confounding events, we provide estimators for the parameter of the normal return model that are not influenced by the returns around the event. Including the event window in the estimation of the normal model parameters could lead to the event returns having a large influence on the normal return measure. In this situation, both the normal returns and the abnormal returns would capture the event impact. Specifically, Fama \& French (1993) developed the three-factor model under the assumption that market beta does not encapsulate every dimension of risk borne by an investment. They assess the impact of additional variables, namely size and book-to-market ratio, to explain 
stock returns. The model, given in Eq. (1), is estimated as following: the three factors in 3-factor model are: market return $\left(R_{t}^{M K T}\right)$, size portfolio return $\left(S M B_{t}\right)$ and book-to market portfolio return $\left(H M L_{t}\right)$.

$$
R_{i t}=\beta_{0}+\beta_{1} R_{i, t}^{M K T}+\beta_{2} S M B_{i, t}+\beta_{3} H M L_{i, t}+\varepsilon_{i t}
$$

where $=\beta_{0}$ the intercept of the model $;=R_{i, t}^{M K T}$ the excess return on the market; $H M L$ (High Minus Low) and SMB (Small Minus Big)=average returns on two factormimicking portfolios for size and book-to-market equity; $R_{i, t}^{M K T}, S M B_{i, t},=H M L_{i, t}$ the results of a multivariate regression of the returns of security $i$ on the three factors $R_{i, t}^{M K T}, H M L$ and $S M B$ for the estimation period.

The model estimates the raw returns on firm's stock, the market returns, the small-minus-big market capitalization portfolio returns $(S M B)$, and the high-minuslow book equity/market equity portfolio returns $(H M L)$. Because we consider the European banks' stock prices, we use the Eurostoxx Value, Eurostoxx Growth, Eurostoxx Small and Eurostoxx Large indexes to build Fama and French (1993) size and growth daily factor returns in the Euro Area. To calculate the daily abnormal returns around different event windows we compute the abnormal returns as a direct measure of an unexpected change in a stock price associated to the event under consideration. An abnormal stock price effect associated with an unanticipated event should be observed if the event has information content. Information is defined as "material" when the abnormal return is statistically significant, where the difference between the returns and the predicted returns is based on economic grounds. In our case, we expect to obtain significant results under the perspective that QE announcements change banks' behaviour and incentives. The calculation of the abnormal returns corresponds to the difference between the observed returns and the expected returns obtained with the different models as given in Eq. (2):

$$
A R_{i t}=R_{i t}-E\left(R_{i t}\right)
$$

where $A R_{i t}$ is the Abnormal Return for stock $i$ on day $t$. Consistent with previous literature, we aggregate the $A R_{i t}$ over each event window and we finally calculate the cumulative abnormal returns $\left(C A R s_{i t}\right)$ for each bank stock price.

$$
\text { CARsi, } t=\sum_{t=1}^{n} A R_{i t}
$$

We run the standardized cross-sectional test by Boehmer et al. (1991) as modified in Kolari and Pynnönen (2010) that is used for statistical inference. The advantage of Boehmer, Musumeci, and Poulsen's standardized cross-sectional t-statistic over other standardized t-tests is that it adjusts for changes in stock return volatility around the event announcements (see Harrington \& Shrider, 2007). Beginning with this t-statistic, in recent work Kolari and Pynnönen develop an adjusted t-test that additionally considers the cross-sectional correlation when event days are clustered. Because all the banks in the sample are affected by at least one of the six common event announcements in our analyses, this new test adjusts for potential dependence between abnormal returns. We also test the number of CARs using the generalized 
sign Z-test. This test is based on a normal approximation to the binomial distribution and tests the null hypothesis that the fraction of returns is the same in the event window and estimation period.

\subsection{Models for cross-sectional analyses}

We test the cross-sectional variation (hypothesis H2) in banks' stock price reactions to the key events corresponding to the announcements of QE programme. We investigate whether bank characteristics influence investors' valuation, namely, if the financial soundness of European banks prior to the QE is somehow reflected into investors' reactions adopting the following model:

$$
\begin{aligned}
\text { CARs }_{i, t}= & \beta_{0}+\beta_{1} \text { Capital Adequacy }_{i, t}+\beta_{1}{\text { Asset } \text { Quality }_{i, t}} \\
& +\beta_{2} \text { Risk Exposure }_{i, t}+\text { Controls }+ \text { Year_FE }+ \text { Country_FE }+\varepsilon_{i, t}
\end{aligned}
$$

The bank characteristics correspond to the explanatory variables and precisely the capital adequacy includes the regulatory capital (Tier1), as the main indicator of stability and robustness of a bank. In accordance with Basel II Framework, the regulator set the minimum capital requirement at $8 \%$. While the total regulatory capital buffer is the difference between the total regulatory capital ratio (i.e., the ratio of Tier 1 and Tier 2 capital to risk weighted assets) and a constant (8\%), to simplify, we use the total regulatory capital ratio instead of total regulatory capital buffer (Kim \& Sohn, 2017). The asset quality refers to: (1) liquid assets over total assets (LiquidAss_TA), where assets with a high credit quality become more liquid outside periods of financial market distress (Rösch \& Kaserer, 2014); (2) loans over total assets (Loans_TA); (3) loan loss provisions over total loans (LLP_Tloans) and (4) non-performing-loans to total assets (NPL_TA) (Kanagaretnam et al., 2011, 2014a, b; Dal Maso et al., 2018). The risk exposure of the bank is identified in the variable of risk-weighted assets ( $R W A s)$, such as the exposure in terms of credit, liquidity and operational risks over total assets (Ferri \& Pesic, 2017). As control variables we include in the model: the percentage of GDP growth rate (GDP growth) at countrylevel, the size (log of total assets) and the book leverage (Book leverage) (De Angelo and Stulz, 2015). Finally, we also consider two agency cost variables (Archer et al., 1998), such as the dividend pay-out, measured as common stock dividends plus preferred stock dividends over net income and the risk-taking behaviour, where the total risk is the average annual standard deviation of daily stock returns (Minton et al., 2014). While the dividend policy affects the levels of regulatory capital with consequences also in term of liquidity (Gropp \& Heider, 2010), the risk-taking behaviour directly affects the level of risk exposure, including the liquidity risk, of a bank (Bushman et al., 2018).

Given the potential incentives to employ the unexpected external liquidity in different ways other than restoring the lending channel to banks, we deem timely assessing what affects the magnitude of the investors' reactions upon the announcements. In particular, we identify in the model as dependent variable the cumulative abnormal returns (CARs) for all the events, and as explanatory variables, the 
banking features, such as those regulatory factors able to influence the banks' valuation of investors as well as to mitigate the benefits of the new liquidity injection provided by ECB QE. Aware that a country dimension coming from the past, in terms of regulation and supervision, can affect the observations related to the banks included in our sample (Bruno et al., 2016), in our model we include country fixed effects (Country_FE) and year fixed effects $\left(Y e a r_{-} F E\right)$ to control for the presence of other confounding events and timely trends affecting our observed time-period. We cluster the robust standard errors by banks to control for non-constant error variance and the time dependency of errors for all the banks included in the sample.

All the analyses incorporate aspects at individual-level emphasizing how a bank can appear sound and stable and consequently solvent given several considerations coming from inside and outside the same bank. Investors might value the injection of new liquidity as a further support for all those weak banks finally incentivized to invest again in better asset quality decreasing their leverage and improving their liquidity; or they might also value the new liquidity provision as an opportunity for banks to improve or to meet the regulatory ratios. On the base of all these considerations, we conduct several tests on a full sample of banks and in a second stage, splitting the sample of the European banks on two subsamples around the threshold of the regulatory ratio Tier1 (first and third quartile of Tierl) identifying the well and not well-capitalized banks, where the first one has consistently maintained a capital buffer above the threshold required by the regulator (Stolz \& Wedow, 2011).

\subsection{Data and sample}

We use Orbis Bank Focus database to gather financial statement information for the period 2014-2016 from a sample of European banks located in the Euro zone. We select all listed commercial banks, the first largest per country in the European area, because of the highest probability to present purchasable assets mainly composed by governmental bonds to exchange on the secondary market with the European Central Bank3F. ${ }^{4}$ For all these listed European banks we gather the market data from the data source Datastream Eikon Thomson Reuters, such as the daily banks' stock price, market value and book equity value, and several European market indexes (StoxxEurope600, StoxxEurope50, S\&PEuro, FTSEEurotop100, FTSE Eurofirst100, FTSEEurofirst80_-“Appendix 2"-Panel B).

We obtain a sample of 120 European banks belonging to different European countries. We focus our attention at bank-level characteristics for two reasons: the first one is that all these banks are involved in the process of the European Banking Union (EBU), such as all these listed commercial banks will be supervised by the European Central Bank and no longer by national supervisors (Nielsen \& Smeets, 2018); the second one is that's these banks are regulated by the same accounting and

\footnotetext{
4 This is the list of eligible assets disclosed on ECB website. It reports the ISIN code and the issuer, that is mainly a national government of a Euro zone country: https://www.ecb.europa.eu/paym/coll/assets/ html/index.en.html.
} 
financial rules based on both IFRS and Basel Frameworks (Agoraki et al., 2011). Moreover, we decide to identify different groups of banks included in our sample, exploiting which banks are in countries joining the Quantitative Easing program $\left(Q E \_b a n k s\right),{ }^{5}$ the Euro zone (Euro_banks) and the European Union (EU_banks). There are also other groups of banks based on PIIGS classification (PIIGS_banks), such as those countries affected mostly by the sovereign debt-crisis starting from 2011: Portugal, Italy, Ireland, Greece and Spain (Rossignolo et al., 2013) and finally banks that belong to those countries with a regulation providing pre-existing liquidity ratios before complying Basel III framework (Ex_LR_banks): Germany, The Netherlands, Switzerland, Denmark and the United Kingdom (Bruno et al., 2016).

We identify three fundamental categories reflecting the financial stability and economic soundness of each bank and defined as the outcome of specific regulation and capital management choices: (1) the capital adequacy, (2) the asset quality and (3) the risk exposure. Even though prior research studies related to the banking industry focus mostly on CAMELS ratings (Betz et al., 2014), we choose those bank characteristics based on the topic issues of those Transparency exercises and Stress tests conducted by the European Banking Authority on European banks (Calomiris et al., 2015; Klomp \& Haan, 2012). In detail, the capital adequacy includes the regulatory capital proxied by the Tier1 ratio (Tier1), such as that source able to absorb any financial distress as well as any negative externalities (Beltratti \& Stulz, 2012; Berger \& Bouwman, 2013; Laeven, 2013). From an accounting perspective the regulatory capital is composed by book value of common shares, paid in capital, retained earnings, less goodwill, and any other intangibles, plus other instruments subordinated to subordinated debt with no fixed maturity and no embedded incentive for redemption and for which a bank can cancel dividends or coupons at any time. This proxy has become a sort of first "traffic light" for the supervisor and for the investors valuing the robustness of a bank (Petrella \& Resti, 2013).

On one side, we see that European banks present a homogenous approach to the regulation, and at the other side, the same banks simultaneously present a high heterogeneity in terms of asset side of their balance sheet because of the different strategies and management capital choices. The asset quality refers to capturing the size of the liquid assets (liquid assets divided by total assets), the amount of loans (loans divided by total assets), the loan loss provisions (loan loss provisions divided by total loans) and the non-performing loans (non-performing loans divided by total assets). The liquid assets (LiquidAss_TA) represent the level of liquidity measuring the ability to transform, in thirty calendar days, the marketable securities in cash (Hong et al., 2014). Concerning the asset quality, especially relevant from a supervisor's perspective, we consider the ratio of total loans over total assets (Loans_TA) pointing out that banks could be inclined to lend less and to rely more on borrowing through typically short-term repurchase agreements (potentially collateralized by held to maturity securities) in a way to create new liquidity for the same bank. We also consider under the category of the asset quality other two bank characteristics:

\footnotetext{
5 Two countries have been excluded a priori from joining the Quantitative Easing program (Greece and Cyprus).
} 
Table 1 Sample composition and summary statistics: Panel $A$ This table reports the distribution (by country) of the 120 European banks included in the study

\begin{tabular}{llllll}
\hline Country (1) & $\begin{array}{l}\text { Country code } \\
(2)\end{array}$ & $\begin{array}{l}\text { Nr. Listed } \\
\text { Banks (3) }\end{array}$ & QE (4) & Euro zone (5) & EU (6) \\
\hline Austria & AT & 6 & Yes & Yes & Yes \\
Belgium & BE & 1 & Yes & Yes & Yes \\
Cyprus & CY & 1 & No & Yes & Yes \\
Finland & FI & 2 & Yes & Yes & Yes \\
France & FR & 4 & Yes & Yes & Yes \\
Germany & DE & 5 & Yes & Yes & Yes \\
Ireland & IE & 1 & Yes & Yes & Yes \\
Italy & IT & 16 & Yes & Yes & Yes \\
Malta & MT & 3 & Yes & Yes & Yes \\
Netherlands & NL & 2 & Yes & Yes & Yes \\
Portugal & PT & 1 & Yes & Yes & Yes \\
Slovakia & SK & 3 & Yes & Yes & Yes \\
Spain & ES & 6 & Yes & Yes & Yes \\
Denmark & DK & 22 & No & No & Yes \\
Norway & NO & 21 & No & No & No \\
Sweden & SE & 4 & No & No & Yes \\
Switzerland & CH & 17 & No & No & No \\
United Kingdom & GB & 5 & No & No & Yes \\
Total banks & & 120 & & & \\
\hline
\end{tabular}

The time period ranges from 2014 to 2016. Columns 4,5 and 6 reflect country participation in the Quantitative Easing program (QE), the Euro zone and the European Union. All the banks included in the sample are under the IFRS regulation and Basel III Framework regulation

the loan loss provisions (LLP_Tloans) and the nonperforming loans (NPL_TA) following Dal Maso et al. (2018).

The most revolutionary issue around the last financial crisis (2007-2009) was how to measure the risk of a bank under the perspective to forecast a future financial distress. The risk exposure of a bank identified in the risk weighted assets ratio $(R W A s)$ is that driver able to indicate when the regulatory capital can be undermined. Furthermore, the RWAs ratio can show a potential fragility of a bank, even when this bank respects the regulatory capital ratio, because the risk exposure indicates the risks of all the activities of a bank (credit risk, liquidity risk and operational risk). The risk weighted assets minimum requirement is fixed at the threshold of $1.25 \%$, and it works under the mechanism "more the regulatory capital increases, more the RWAs decreases". In our case, we consider the ratio of the risk-weighted assets over total assets ( $\left.R W A s_{-} T A\right)$.

Tables 1, 2, 3, and 4 presents the sample composition and the summary statistics (Panel A, Panel B and Panel C). First, we report the distribution of the listed commercial banks included in our sample for each European country. Following, we sum up the descriptive statistics split on: number of observations $(\mathrm{Obs})$, mean 
Table 2 Sample composition and summary statistics: Panel B This table presents the summary statistics (mean, median, max, min, standard deviation) for all the European banks included in the sample for the time period covering the year 2015

\begin{tabular}{llllll}
\hline Variable & Obs & Mean & Std. Dev & Min & Max \\
\hline CARs & 351 & -0.026 & 0.046 & -0.295 & 0.155 \\
Tier1 & 117 & 0.150 & 0.048 & 0.000 & 0.313 \\
Total Assets $(€$ th) & 117 & 150,000 & 342,000 & 12,837 & $1,999,000$ \\
LiquidAs_TA & 117 & 0.201 & 0.144 & 0.009 & 0.799 \\
Loans_TA & 117 & 0.620 & 0.189 & 0.050 & 0.903 \\
LLP_Tloans & 117 & 0.008 & 0.018 & 0.001 & 0.016 \\
NPL_TA & 117 & 0.005 & 0.007 & 0.000 & 0.037 \\
RWAs_TA & 117 & 0.489 & 0.205 & 0.000 & 0.917 \\
Mortgage loans_TA & 117 & 0.136 & 0.239 & 0.000 & 0.869 \\
Consumer loans_TA & 117 & 0.157 & 0.248 & 0.000 & 0.865 \\
Corporate loans_TA & 117 & 0.091 & 0.165 & 0.000 & 0.763 \\
Securities_TA & 117 & 0.104 & 0.090 & 0.001 & 0.392 \\
FixedAss_TA & 117 & 0.084 & 0.062 & 0.000 & 0.297 \\
Total Liabilities $(€$ th) & 117 & 141,000 & 325,000 & 11,342 & $1,900,000$ \\
Deposits_TL & 117 & 0.142 & 0.033 & 0.006 & 0.194 \\
ShortTermFund\&DebtSec_TL & 117 & 0.026 & 0.040 & 0.000 & 0.244 \\
Subordinated debt_TL & 117 & 0.008 & 0.103 & 0.000 & 0.040 \\
Total Equity $(€$ th) & 117 & 8,330 & 16,700 & 1,346 & 96,800 \\
Dividend Payout & 117 & 0.053 & 0.052 & 0.000 & 0.147 \\
Risk-taking & 117 & 0.013 & 0.020 & 0.000 & 0.255 \\
\%_GDP & 117 & 0.016 & 0.014 & 0.015 & 0.084 \\
Book leverage & 117 & 0.131 & 0.048 & 0.053 & 0.306 \\
\hline Alt & & & &
\end{tabular}

All the definitions of variables are reported in "Appendix 2"-Panel A

(Mean), standard deviation (Std. Dev.) and minimum and maximum (Min and Max) for the dependent variable (the cumulative abnormal returns-CARs), and the explanatory variables (bank characteristics and the asset and liability's components) and the control variables used for our cross-sectional analyses among the European banks. The definitions of all the variables are reported in "Appendix 2" (Panel A), while the number of the observation changes from the year 2015 (nr. 117 unique bank-observations) to the year 2016 (nr. 120 unique bankobservations). The number of observations of CARs in 2015 is based on the first $\mathrm{QE}$ three announcements identified around a three-days event window, while the number of observations of CARs in 2016 is based on the last three QE announcements again, identified around a three-days event window.

While CARs are the output of the market assessments of the QE programme, the explanatory variables are a proxy of the bank's prior conditions driving the same market assessments. We see in Table 3 (Panel C) that Tierl ratio has a mean of 0.154 . Focusing on the asset quality, we find a mean for liquid assets ratio of 0.205 , for loans divided by total assets of 0.623 , for loan loss provisions divided by total 
Table 3 Sample composition and summary statistics: Panel $C$ This table presents the summary statistics (mean, median, max, min, standard deviation) for all the European banks included in the sample for the time period covering the year 2016

\begin{tabular}{|c|c|c|c|c|c|}
\hline Variable & Obs & Mean & Std. Dev & Min & Max \\
\hline$C A R s$ & 360 & -0.048 & 0.081 & -0.376 & 0.193 \\
\hline Tier1 & 120 & 0.154 & 0.050 & 0.000 & 0.296 \\
\hline Total Assets ( $€$ th) & 120 & 151,000 & 347,000 & 13,012 & $2,080,000$ \\
\hline LiquidAss_TA & 120 & 0.205 & 0.146 & 0.008 & 0.749 \\
\hline Loans_TA & 120 & 0.623 & 0.190 & 0.048 & 0.889 \\
\hline LLP_Tloans & 120 & 0.005 & 0.007 & 0.001 & 0.033 \\
\hline$N P L \_T A$ & 120 & 0.005 & 0.007 & 0.000 & 0.041 \\
\hline$R W A s \_T A$ & 120 & 0.481 & 0.203 & 0.000 & 0.961 \\
\hline Mortgage loans_TA & 120 & 0.143 & 0.244 & 0.000 & 0.891 \\
\hline Consumer loans_TA & 120 & 0.154 & 0.250 & 0.000 & 0.868 \\
\hline Corporate loans_TA & 120 & 0.178 & 0.195 & 0.000 & 0.793 \\
\hline Securities_TA & 120 & 0.102 & 0.094 & 0.007 & 0.382 \\
\hline FixedAss_TA & 120 & 0.088 & 0.066 & 0.000 & 0.278 \\
\hline Total Liabilities ( $€$ th) & 120 & 142,000 & 329,000 & 12,736 & $1,980,000$ \\
\hline Deposits_TL & 120 & 0.144 & 0.032 & 0.061 & 0.196 \\
\hline ShortTermFund\&DebtSec_TL & 120 & 0.024 & 0.041 & 0.000 & 0.029 \\
\hline Subordinated debt_TL & 120 & 0.009 & 0.011 & 0.000 & 0.057 \\
\hline Total Equity ( $€$ th) & 120 & 8,509 & 17,000 & 1,358 & 96,800 \\
\hline Dividend Payout & 120 & 0.054 & 0.054 & 0.000 & 0.147 \\
\hline Risk-taking & 120 & 0.013 & 0.021 & 0.000 & 0.255 \\
\hline$\% \Delta G D P$ & 120 & 0.017 & 0.026 & 0.002 & 0.230 \\
\hline Book leverage & 120 & 0.127 & 0.047 & 0.057 & 0.308 \\
\hline
\end{tabular}

CARs are reported for the three events identified in the year 2016. All the definitions of variables are reported in "Appendix 2" - Panel A

loans of 0.005 and finally for the nonperforming loans divided by total assets of 0.005 . The risk weighted assets ratio presents a mean of 0.489 with a maximum of 0.917 meaning that there are banks strongly exposed to risk. Finally, Panel D reports the correlation matrix of all the variables included in our empirical tests.

\section{Results}

\subsection{Investors' response to $Q E$ announcements}

We first discuss the results obtained through the development of the event study for the sample of European banks around the six QE liquidity injection announcements. Table 5 (Panel A) reports the results among three different event-windows identified in $(-1,+1)$, $(-2,+2),(-1,+3)$ following the methodology of the Fama-French three factor-model (Eqs.1, 2, 3). The cumulative abnormal returns (CARs) show an overall negative and 


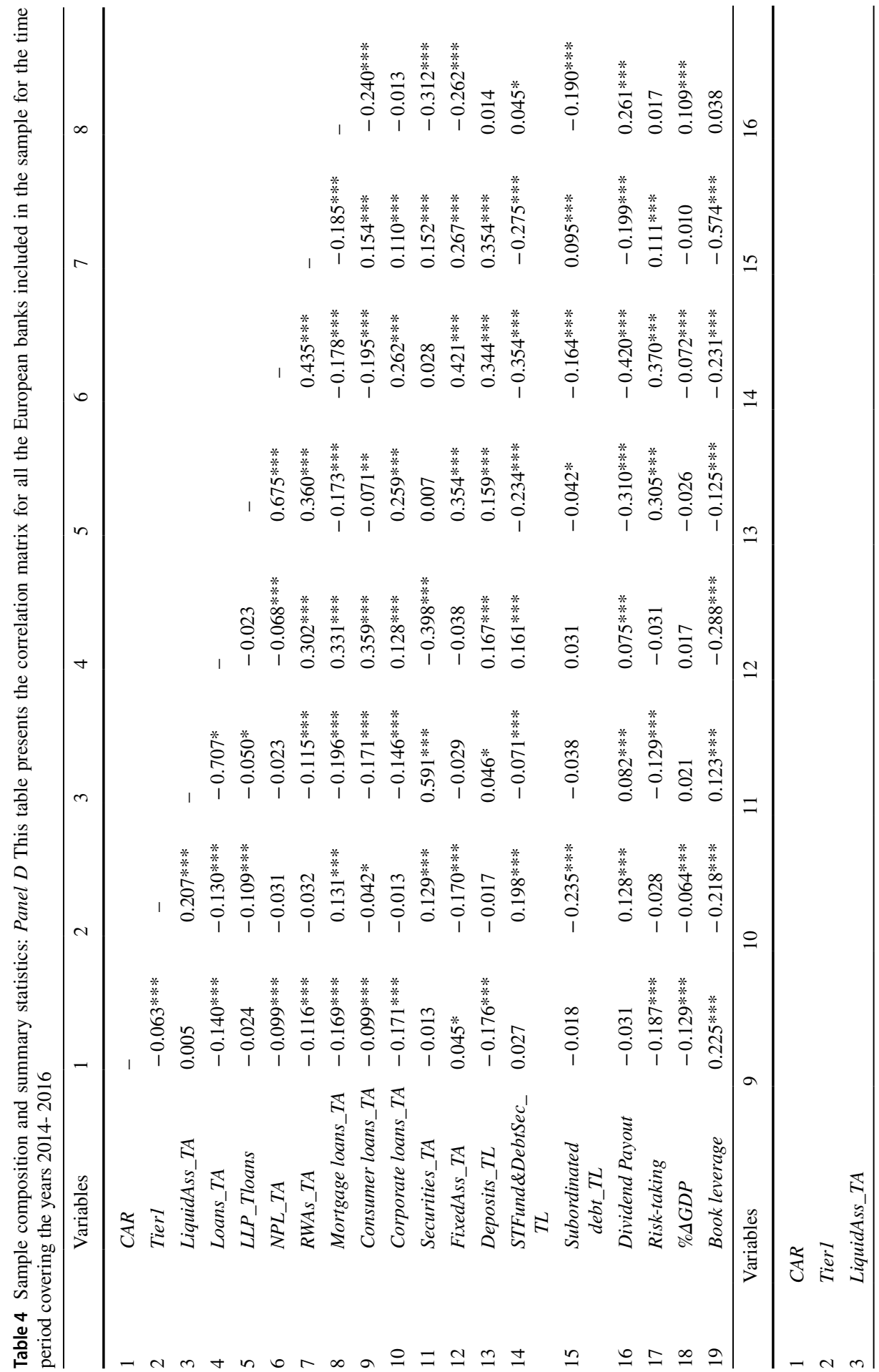




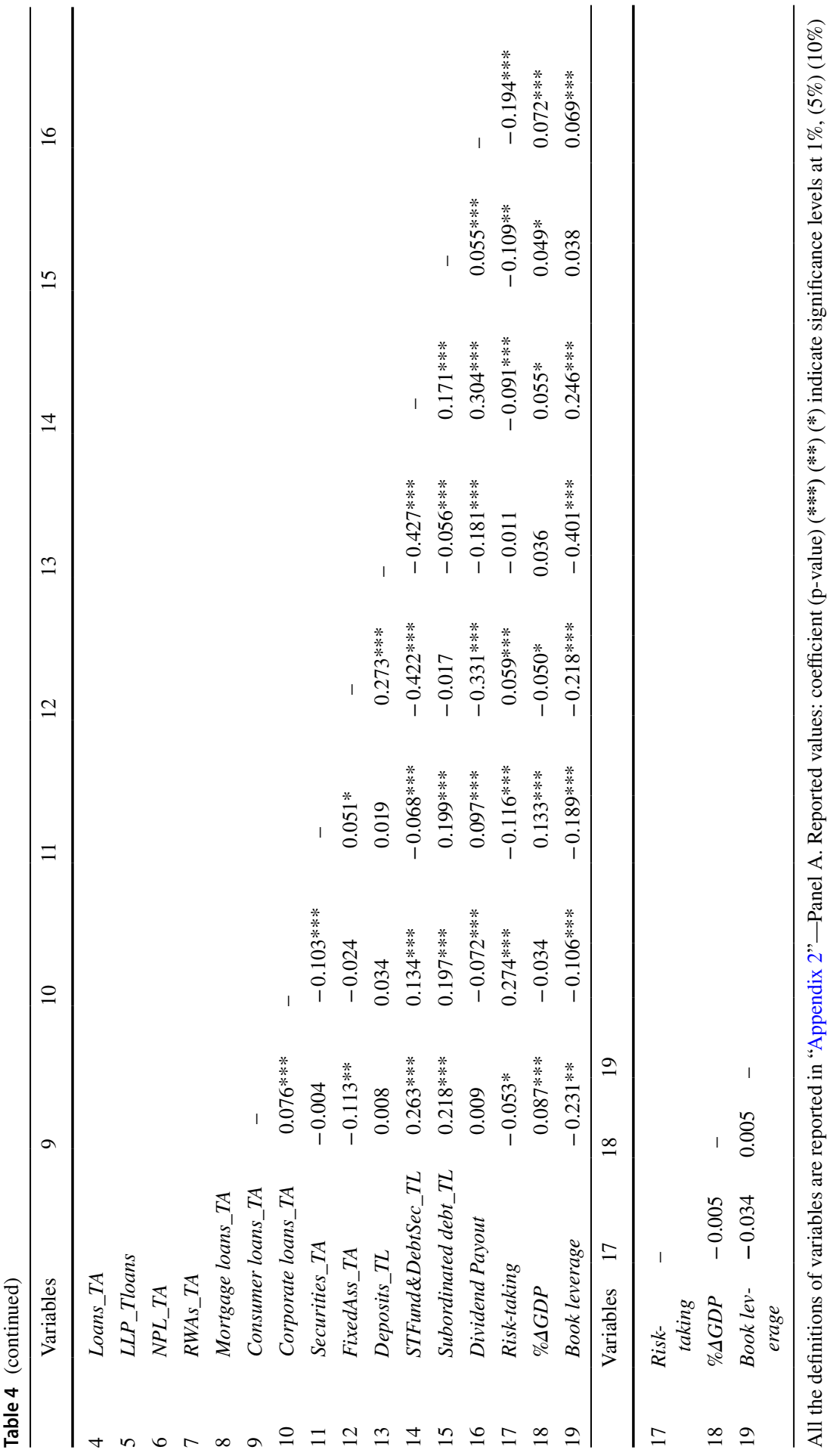


significant market reaction for each event among the years 2015-2016. Whilst surprising, we interpret this as investors being sceptical about expected benefits of new liquidity provisions injected by ECB among the European banks. Because the banks included in our sample belong to different European countries, we run the regressions of the event study grouping banks at country-level. Table 6 (Panel B) provides the results related to the development of the event study, grouping banks to several typologies of countries. We show an overall negative and significant market reaction, even though it is lower $(-0.017)$ for European banks belonging to the PIIGS countries (Rossignolo et al., 2013). Furthermore, Table 7 (Panel C) presents the results of the market reaction estimation by country: we find positive and significant $C A R s$ just for stock prices of banks located in Italy for the first announcement, when the ECB President Mario Draghi announced the adoption of the Quantitative Easing for the first time in the Euro zone (January, 22nd 2015). For the rest of the sample, we find a negative and significant market reaction at country-level. Given these first empirical evidences and awareness of the fact that liquidity provided by ECB offers banks a tool that may be used differently across banks to serve various purposes, we decide to further exploit the market assessments at bank-level by additional analyses. Table 8 (Panel D) reports pairwise comparison of CARs by listing the level of bank capitalization and the classification of bank located in one of the PIIGS countries. Well capitalized bank is an indicator variable taking the value of 1 if the observation stems from adequately capitalized banks which the regulatory capital ratio-Tier 1 - is above the third quartile (75p) when the median of the ratio is $17 \%$ and the value of 0 if the observation stems from not well-capitalized banks which the regulatory capital ratioTier 1 - is lower of the first quartile (25p). PIIGS_bank is an indicator variable taking the value of 1 if the observation stems from banks located in those countries affected mostly by the sovereign debt-crisis starting from 2011 (Rossignolo et al., 2013), and 0 otherwise. We find significant differences between the several combinations of the groups of banks. It is particular to see also a higher negative reaction $(-0.080)$ when banks are well capitalized and located in PIIGS countries.

\subsection{Cross-sectional analyses of Cumulative Abnormal Returns (CARs)}

We run further empirical tests and focused on specific banks characteristics splitting banks on different levels of regulatory capital. Table 9 presents the results of the cross-sectional analyses conducted for testing the second hypothesis (H2). At this stage we split again the full sample of the European banks in well and not well capitalized banks. Here, Wellcapitalized bank is an indicator variable taking the value of 1 if the observation stems from adequately capitalized banks, which the regulatory capital ratio-Tierl-is above the third quartile (75p) when the median of the ratio is $17 \%$. We then assign the value of 0 if the observation stems from not well-capitalized banks which the regulatory capital ratio-Tierl-is lower than the first quartile (25p) when the median of the ratio is $17 \%$. The results show, when we include the control variables (Dividend Pay-out, Risk-taking, $\% \Delta G D P$, Book leverage, Size) and the year (Year_FE) and country (Country_FE) fixed effects, a positive and significant association $(0.002 * *)$ between the cumulative abnormal returns $(C A R s)$ and the regulatory capital (Tier1) just for the well capitalized banks, while the results show no significant results in the regressions of the not-well capitalized banks 
Table 5 Stock market reactions to the QE liquidity announcements: Panel A This table presents the results of the estimation of abnormal market reactions (e.g. test of H1)

\begin{tabular}{|c|c|c|c|c|c|}
\hline Nr. Event & Date & Count & $\begin{array}{l}\text { CARs } \\
(-1,+1)\end{array}$ & $\begin{array}{l}\text { CARs } \\
(-2,+2)\end{array}$ & $\begin{array}{l}\text { CARs } \\
(-1,+3)\end{array}$ \\
\hline Event_1 & January $22^{\text {nd }}, 2015$ & 117 & $\begin{array}{l}-0.013^{* * * *} \\
(0.002)\end{array}$ & $\begin{array}{l}-0.016^{* * * *} \\
(0.003)\end{array}$ & $\begin{array}{l}-0.013 * * * \\
(0.002)\end{array}$ \\
\hline Event_2 & $\operatorname{March} 3^{\text {rd }}, 2015$ & 117 & $\begin{array}{l}-0.030 * * * \\
(0.003)\end{array}$ & $\begin{array}{l}-0.053^{* * *} \\
(0.005)\end{array}$ & $\begin{array}{l}-0.059 * * * \\
(0.005)\end{array}$ \\
\hline Event_3 & April $15^{\text {th }}, 2015$ & 117 & $\begin{array}{l}-0.035^{* * *} \\
(0.005)\end{array}$ & $\begin{array}{l}-0.078 * * * \\
(0.011)\end{array}$ & $\begin{array}{l}-0.091^{* *} \\
(0.012)\end{array}$ \\
\hline Event_4, & March $10^{\text {th }}, 2016$ & 120 & $\begin{array}{l}-0.055^{* * *} \\
(0.006)\end{array}$ & $\begin{array}{l}-0.123^{* * * *} \\
(0.011)\end{array}$ & $\begin{array}{l}-0.118^{* * *} \\
(0.012)\end{array}$ \\
\hline Event_5 & April $21^{\text {st }}, 2016$ & 120 & $\begin{array}{l}-0.044 * * * \\
(0.007)\end{array}$ & $\begin{array}{l}-0.124 * * * \\
(0.011)\end{array}$ & $\begin{array}{l}-0.122 * * * \\
(0.012)\end{array}$ \\
\hline Event_6 & July $22^{\text {nd }}, 2016$ & 120 & $\begin{array}{l}-0.043^{* * *} \\
(0.007)\end{array}$ & $\begin{array}{l}-0.139 * * * \\
(0.011)\end{array}$ & $\begin{array}{l}-0.140 * * * \\
(0.012)\end{array}$ \\
\hline
\end{tabular}

The event study follows the Fama-French three factor model to estimate the cumulative abnormal returns $(\boldsymbol{C A R S})$. Further details about the adopted methodology are reported in "Appendix 1". All the data related to the daily stock price, the market index price (Stoxx Europe 600 (We consider several other European market indexes such as the S\&P euro (speurop), the Ftse Eurotop 100 (fteu100), the Ftse Eurofirst 100 (ftefc1e), the Ftse Eurofirst 80 (ftef80e) and the STOXX Europe 50 (djes50i)—all defined in “Appendix 2", Panel B. The robustness check confirms that results still hold.)), the market value and the book value of equity are retrieved from Thomson Reuters-Datastream Eikon. The CARs are provided for each event under three event windows identification composed by three or five days including the day of the announcement: $(-1 ;+1),(-2 ;+2)$ and $(-1 ;+3)$. Reported values: coefficient (p-value) $(* * *)$ $(* *)(*)$ indicate significance levels at 1\%, (5\%) (10\%). Clustered standard errors are given in parentheses. The computation of the CARs is based on the following model (Eqs. 1, 2, 3):

Table 6 Stock market reactions to the QE liquidity announcements: Panel B This table presents the results of the stock price reactions to the various QE announcements of liquidity injection; these reactions are identified through the cumulative abnormal returns $(\boldsymbol{C A R s})$ by grouping specific countries

\begin{tabular}{llllll}
\hline CARs $(-1,+1)$ & \multicolumn{1}{l}{} \\
\hline All_sample & QE_banks & Euro_banks & PIIGS_banks & EU_banks & Ex_LR_banks \\
\hline$-0.037^{* * * *}$ & $-0.016^{* * * *}$ & $-0.025^{* * * *}$ & $-0.017^{*}$ & $-0.031^{* * * *}$ & $-0.048^{* * *}$ \\
$(0.002)$ & $(0.003)$ & $(0.004)$ & $(0.007)$ & $(0.003)$ & $(0.003)$
\end{tabular}

We identify several groups of countries according to the location of each European bank's headquarter. $\boldsymbol{A} \boldsymbol{I l} \_\boldsymbol{s a m p l e \_ b a n k s}$ are the group of banks included in the sample of the research study. $\boldsymbol{Q} \boldsymbol{E} \_\boldsymbol{b a n k s}$ correspond to the group of banks located in countries potentially affected by the Quantitative Easing program (Greece and Cyprus are the only two countries excluded from the QE). Euro_banks correspond to the group of banks located in countries under the Euro Union. PIIGS_banks correspond to the group of banks located in those countries affected mostly by the sovereign debt-crisis starting from 2011 (Petrella \& Resti, 2013; Rossignolo et al., 2013). EU_banks correspond to the group of banks located in countries of the European Union (we recall that UK is no more an EU country after Brexit, June 2016). Ex_LR_ banks correspond to the group of banks located in those countries affected by higher regulatory liquidity ratios before Basel III Framework (Bruno et al., 2016). The results are provided for all the events under one event window composed by three days including the day of the announcement: $(-1 ;+1)$. Reported values: coefficient (p-value) $(* * *)(* *)(*)$ indicate significance levels at $1 \%,(5 \%)(10 \%)$. Clustered standard errors are given in parentheses 
subsample with the exception of RWAs positively and significantly associated with CARs $(0.004 *)$.

These findings highlight that the ex-ante QE conditions would allow to be stronger and more stable for just the well-capitalized banks, while the not well-capitalized banks run the risk to become weaker. Furthermore, investors do not expect that European banks would ameliorate themselves in terms of risk exposure thanks to the QE liquidity injection. Although the regulator addresses in a first time (Basel II Framework) the efforts to establish a threshold for the RWAs as a buffer for banks to attenuate any kind of financial turbulences designed by market risk, liquidity risk, credit risk and operational risk, we find results reflecting potential lower risk exposure for European banks $\left(0.003^{* * *}\right)$, both well and not well capitalized banks. According with these first results, it is evident that the first benefits for European banks are concentrated on two sides: the capital adequacy and the risk exposure. Given the high heterogeneity among this sample of banks, we see that the outcomes of our analyses assume an economic significance just in the moment we split the sample on different levels of regulatory capital5F. ${ }^{6}$

\subsection{Additional analyses}

We perform further additional tests to probe the robustness of our results. First, as suggested by Ricci (2015) we conduct the event study with a standard market model (Mackinlay, 1997), where the computation of the returns $\left(R_{i t}\right)$ is based on a simpler following model:

$$
R_{i t}=\beta_{0}+\beta_{1} R_{i, t}^{M K T}+\varepsilon_{i t}
$$

Table 10 presents the results of the CARs estimated on the above standard market model. The CARs are provided for each event under the three event windows composed by three or five days including the day of the announcement: $(-1,+1)$; $(-2,+2)$ and $(-1,+3)$. In this case we find a smaller magnitude according to the results obtained with the Fama-French three factor model.

Furthermore, following the Fama-French three factor model we replace the main financial market index (Stoxx Europe 600) with other different European market indexes like the S\&P euro (speurop), the Ftse Eurotop 100 (fteu100), the Ftse Eurofirst 100 (ftefcle), the Ftse Eurofirst 80 (ftef80e) and the STOXX Europe 50 (djes50i). All the findings are still consistent with those reported in a first time. The description of the market indexes is reported in detail in "Appendix 2" (Panel B).

To qualify the drivers of the market reactions, we exploit banks' heterogeneity considering specific components of banks' balance sheets according to the level of banks' capitalization (Laux \& Rauter, 2017). The theoretical reason under which

\footnotetext{
${ }^{6}$ We conducted further analyses to test the second hypothesis (H2), splitting the full sample of the European banks in well and not well capitalized banks. Here, Well-capitalized bank is an indicator variable taking a value of 1 if the observation stems from adequately capitalized banks, which the regulatory capital ratio-Tier1 - is above the third quartile (75p) when the threshold of the ratio is $8 \%$, and taking a value of 0 if the observation stems from not well-capitalized banks, which the regulatory capital ratioTier1-is lower than the first quartile $(25 \mathrm{p})$ when the threshold of the ratio is $8 \%$. We again obtain a positive and significant association $\left(0.001^{* * *}\right)$ between the cumulative abnormal returns $(C A R s)$ and the regulatory capital (Tier1) only for the well-capitalized banks.
} 
Table 7 Stock market reactions to the QE liquidity announcements: Panel $C$ The table presents the results of the market reaction estimation by country

\begin{tabular}{|c|c|c|c|c|c|c|}
\hline Country & Event 1 & Event 2 & Event 3 & Event 4 & Event 5 & Event 6 \\
\hline AT & $\begin{array}{l}-0.026^{* * * *} \\
(0.002)\end{array}$ & $\begin{array}{l}-0.033^{* * *} \\
(0.002)\end{array}$ & $\begin{array}{l}-0.037 * * * \\
(0.003)\end{array}$ & $\begin{array}{l}-0.047^{* * *} \\
(0.003)\end{array}$ & $\begin{array}{l}-0.041^{* * * *} \\
(0.004)\end{array}$ & $\begin{array}{l}-0.040 * * * \\
(0.004)\end{array}$ \\
\hline $\mathrm{BE}$ & $\begin{array}{l}-0.013 * * * \\
(0.002)\end{array}$ & $\begin{array}{l}-0.027 * * * \\
(0.003)\end{array}$ & $\begin{array}{l}-0.032^{* * * *} \\
(0.004)\end{array}$ & $\begin{array}{l}-0.050 * * * \\
(0.005)\end{array}$ & $\begin{array}{l}-0.040 * * * \\
(0.006)\end{array}$ & $\begin{array}{l}-0.039 * * * \\
(0.007)\end{array}$ \\
\hline $\mathrm{DE}$ & $\begin{array}{l}-0.030 * * * \\
(0.003)\end{array}$ & $\begin{array}{l}-0.039 * * * \\
(0.003)\end{array}$ & $\begin{array}{l}-0.042^{* * * *} \\
(0.003)\end{array}$ & $\begin{array}{l}-0.053^{* * *} \\
(0.004)\end{array}$ & $\begin{array}{l}-0.046^{* * * *} \\
(0.004)\end{array}$ & $\begin{array}{l}-0.045^{* * * *} \\
(0.005)\end{array}$ \\
\hline ES & $\begin{array}{l}-0.011^{* * *} \\
(0.003)\end{array}$ & $\begin{array}{l}-0.019 * * * \\
(0.003)\end{array}$ & $\begin{array}{l}-0.022^{* * * *} \\
(0.004)\end{array}$ & $\begin{array}{l}-0.033^{* * *} \\
(0.004)\end{array}$ & $\begin{array}{l}-0.030 * * * \\
(0.005)\end{array}$ & $\begin{array}{l}-0.030 * * * \\
(0.005)\end{array}$ \\
\hline FI & $\begin{array}{l}-0.025^{* * *} \\
(0.003)\end{array}$ & $\begin{array}{l}-0.038 * * * \\
(0.003)\end{array}$ & $\begin{array}{l}-0.042^{* * * *} \\
(0.004)\end{array}$ & $\begin{array}{l}-0.058^{* * *} \\
(0.005)\end{array}$ & $\begin{array}{l}-0.049 * * * \\
(0.006)\end{array}$ & $\begin{array}{l}-0.047^{* * *} \\
(0.006)\end{array}$ \\
\hline FR & $\begin{array}{l}-0.005^{*} \\
(0.002)\end{array}$ & $\begin{array}{l}-0.015^{* * *} \\
(0.003)\end{array}$ & $\begin{array}{l}-0.019^{* * * *} \\
(0.004)\end{array}$ & $\begin{array}{l}-0.031 * * * \\
(0.004)\end{array}$ & $\begin{array}{l}-0.026^{* * * *} \\
(0.005)\end{array}$ & $\begin{array}{l}-0.025^{* * *} \\
(0.005)\end{array}$ \\
\hline GR & $\begin{array}{l}-0.059^{* * * *} \\
(0.006)\end{array}$ & $\begin{array}{l}-0.070^{* * *} \\
(0.006)\end{array}$ & $\begin{array}{l}-0.068^{* * * *} \\
(0.006)\end{array}$ & $\begin{array}{l}-0.080^{* * *} \\
(0.006)\end{array}$ & $\begin{array}{l}-0.075^{* * * *} \\
(0.007)\end{array}$ & $\begin{array}{l}-0.070^{* * * *} \\
(0.007)\end{array}$ \\
\hline IE & $\begin{array}{l}-0.035^{* * * *} \\
(0.006)\end{array}$ & $\begin{array}{l}-0.050 * * * \\
(0.006)\end{array}$ & $\begin{array}{l}-0.053 * * * \\
(0.002)\end{array}$ & $\begin{array}{l}-0.070 * * * \\
(0.007)\end{array}$ & $\begin{array}{l}-0.061^{* * * *} \\
(0.008)\end{array}$ & $\begin{array}{l}-0.060 * * * \\
(0.009)\end{array}$ \\
\hline IT & $\begin{array}{l}0.007 * \\
(0.002)\end{array}$ & $\begin{array}{l}0.002 \\
(0.003)\end{array}$ & $\begin{array}{l}0.008 \\
(0.003)\end{array}$ & $\begin{array}{l}-0.004 \\
(0.003)\end{array}$ & $\begin{array}{l}-0.003 \\
(0.003)\end{array}$ & $\begin{array}{l}-0.003 \\
(0.003)\end{array}$ \\
\hline MT & $\begin{array}{l}-0.028 * * * \\
(0.003)\end{array}$ & $\begin{array}{l}-0.039 * * * \\
(0.003)\end{array}$ & $\begin{array}{l}-0.042^{* * * *} \\
(0.004)\end{array}$ & $\begin{array}{l}-0.056^{* * *} \\
(0.004)\end{array}$ & $\begin{array}{l}-0.048^{* * * *} \\
(0.005)\end{array}$ & $\begin{array}{l}-0.047 * * * \\
(0.006)\end{array}$ \\
\hline NL & $\begin{array}{l}-0.002 * * \\
(0.002)\end{array}$ & $\begin{array}{l}-0.022^{* * *} \\
(0.003)\end{array}$ & $\begin{array}{l}-0.027 * * * \\
(0.004)\end{array}$ & $\begin{array}{l}-0.044 * * * \\
(0.005)\end{array}$ & $\begin{array}{l}-0.036^{* * * *} \\
(0.006)\end{array}$ & $\begin{array}{l}-0.034 * * * \\
(0.007)\end{array}$ \\
\hline PT & $\begin{array}{l}-0.010^{*} \\
(0.004)\end{array}$ & $\begin{array}{l}-0.025^{* * *} \\
(0.004)\end{array}$ & $\begin{array}{l}-0.029 * * * \\
(0.006)\end{array}$ & $\begin{array}{l}-0.047 * * * \\
(0.006)\end{array}$ & $\begin{array}{l}-0.039 * * * \\
(0.007)\end{array}$ & $\begin{array}{l}-0.038 * * * \\
(0.007)\end{array}$ \\
\hline SK & $\begin{array}{l}-0.023^{* * *} \\
(0.002)\end{array}$ & $\begin{array}{l}-0.035^{* * *} \\
(0.002)\end{array}$ & $\begin{array}{l}-0.039^{* * * *} \\
(0.004)\end{array}$ & $\begin{array}{l}-0.053 * * * \\
(0.004)\end{array}$ & $\begin{array}{l}-0.045^{* * * *} \\
(0.005)\end{array}$ & $\begin{array}{l}-0.043^{* * * *} \\
(0.005)\end{array}$ \\
\hline UK & $\begin{array}{l}-0.013 * * * \\
(0.002)\end{array}$ & $\begin{array}{l}-0.030 * * * \\
(0.002)\end{array}$ & $\begin{array}{l}-0.037 * * * \\
(0.002)\end{array}$ & $\begin{array}{l}-0.055^{* * *} \\
(0.006)\end{array}$ & $\begin{array}{l}-0.044 * * * \\
(0.007)\end{array}$ & $\begin{array}{l}-0.043^{* * * *} \\
(0.008)\end{array}$ \\
\hline SUI & $\begin{array}{l}-0.040^{* * * *} \\
(0.002)\end{array}$ & $\begin{array}{l}-0.044 * * * \\
(0.002)\end{array}$ & $\begin{array}{l}-0.045^{* * * *} \\
(0.002)\end{array}$ & $\begin{array}{l}-0.051 * * * \\
(0.002)\end{array}$ & $\begin{array}{l}-0.047 * * * \\
(0.002)\end{array}$ & $\begin{array}{l}-0.046^{* * * *} \\
(0.002)\end{array}$ \\
\hline NOR & $\begin{array}{l}-0.039 * * * \\
(0.002)\end{array}$ & $\begin{array}{l}-0.042^{* * *} \\
(0.002)\end{array}$ & $\begin{array}{l}-0.044 * * * \\
(0.002)\end{array}$ & $\begin{array}{l}-0.048 * * * \\
(0.002)\end{array}$ & $\begin{array}{l}-0.044 * * * \\
(0.002)\end{array}$ & $\begin{array}{l}-0.043 * * * \\
(0.002)\end{array}$ \\
\hline SWE & $\begin{array}{l}-0.015^{* * * *} \\
(0.002)\end{array}$ & $\begin{array}{l}-0.025^{* * *} \\
(0.002)\end{array}$ & $\begin{array}{l}-0.028 * * * \\
(0.003)\end{array}$ & $\begin{array}{l}-0.041^{* * *} \\
(0.004)\end{array}$ & $\begin{array}{l}-0.035^{* * * *} \\
(0.005)\end{array}$ & $\begin{array}{l}-0.034 * * * \\
(0.005)\end{array}$ \\
\hline DEN & $\begin{array}{l}-0.045^{* * *} \\
(0.002)\end{array}$ & $\begin{array}{l}-0.049 * * * \\
(0.002)\end{array}$ & $\begin{array}{l}-0.035^{* * *} \\
(0.005)\end{array}$ & $\begin{array}{l}-0.055^{* * *} \\
(0.002)\end{array}$ & $\begin{array}{l}-0.051^{* * *} \\
(0.003)\end{array}$ & $\begin{array}{l}-0.050 * * * \\
(0.003)\end{array}$ \\
\hline
\end{tabular}

The event study follows the Fama-French three factor model to estimate the cumulative abnormal returns $(\boldsymbol{C A R s})$. The CARs are provided for each event under one event window identification composed by three days including the day of the announcement: $(-1 ;+1)$. Reported values: coefficient (p-value) $* * *(* *)$ (*) indicate significance levels at $1 \%,(5 \%)(10 \%)$. Clustered standard errors are given in parentheses 
Table 8 Stock market reactions to the QE liquidity announcements: Panel D This table reports pairwise comparison of the cumulative abnormal returns (CARs) by listing the level of bank capitalization and the classification of banks located in one of the PIIGS countries

\begin{tabular}{lllll}
\hline & All & $\begin{array}{l}\text { Well-Capitalized } \\
\text { banks }\end{array}$ & $\begin{array}{l}\text { Not Well-Capitalized } \\
\text { banks }\end{array}$ & Diff \\
\hline All & -0.037 & -0.017 & -0.043 & $0.026^{* *}$ \\
PIIGS & -0.017 & -0.080 & -0.016 & $0.064^{* * *}$ \\
$\begin{array}{l}\text { Banks } \\
\text { No PIIGS }\end{array}$ & -0.043 & -0.037 & -0.043 & $0.006^{* * *}$ \\
$\begin{array}{l}\text { Banks } \\
\text { Diff } \\
\text { (PIIGS-No PIIGS) }\end{array}$ & $0.026^{* * *}$ & $0.043^{* * *}$ & $0.027 * * *$ & \\
\hline
\end{tabular}

The average of the $\boldsymbol{C A R}$ based on a three-days event window $(-1 ;+1)$ is obtained through the conduction of the event study. Well-capitalized bank is an indicator variable taking the value of 1 if the observation stems from adequately capitalized banks, which the regulatory capital ratio-Tier1-is above the third quartile (75p) and the value of 0 if Tier1 is lower of the first quartile (25p) when the median of the ratio is 17\%. PIIGS_bank is an indicator variable taking the value of 1 if the observation stems from banks located in those countries affected mostly by the sovereign debt-crisis starting from 2011 (Rossignolo et al., 2013), and 0, otherwise. The significance (p-values) of the difference is obtained via panel regression of $\boldsymbol{C A R S}$ variable on its interaction with Well-capitalized bank and PIIGS_bank for a respective subsample. Reported values: coefficient (p-value) (***) (**) (*) indicate significance levels at $1 \%$, $(5 \%)(10 \%)$

the asset and liability components analyses can assume interesting connotations is because of the different level of risk reflected on each component.

Table 11 (Panel A) presents the results of the component analyses related to the asset side of the European banks' balance sheets. The dependent variable is the cumulative abnormal returns $(C A R s)$ among a three-days event window $(-1 ;+1)$ obtained through the conduction of the event study. The explanatory variables are the main drivers of the asset side of the banks' balance sheets, such as the mortgage loans (Mortgage loans_TA), the consumer loans (Consumer loans_TA), the corporate loans (Corporate loans_TA), the securities assets (Securities_TA) and the fixed assets (FixedAss_TA). The regressions include as control variables Dividend Pay-out, Risk-taking, \% $\Delta$ GDP, Book leverage, and Size and the year (Year_FE) and country (Country_FE) fixed effects. The first column reports the OLS estimations referred to the full sample of European banks, while the second column is referred to the well-capitalized banks and the third column is referred to the not well-capitalized banks.

The regressions are based on the following model:

$$
\text { CARs }_{i, t}=\beta_{0}+\beta_{1} \text { Banks' }^{\prime} \text { asset components }{ }_{i, t}+\text { Controls }+ \text { Year_FE }+ \text { Country_FE }+\varepsilon_{i, t}
$$

The findings show a negative and significant association between CARs and the Mortgage loans_TA $(-0.042 * * *)$ and Corporate loans_TA $(-0.044 * *)$ when we consider the full sample. This is consistent also in the case we consider the not-well capitalized banks, while there are no significant results when we consider the subsample of well capitalized banks. 
Table 9 Stock market reactions and bank level characteristics

\section{$\operatorname{CARs}(-1,+1)$}

Full sample

Tier1

LiquidAss_TA

Loans_TA

LLP_Tloans

NPL_TA

RWAs

Dividend Payout

Risk-taking

$\% \Delta G D P$

Leverage

$\begin{array}{ll} & (0.006) \\ \text { Size } & 0.007 * * * \\ & (0.001)\end{array}$

Constant

Year_FE

Country_FE

Observations

$R$-squared

Prob $>$ F
Well-capitalized banks

(2)

$0.002 * *$
$(0.001)$

$-0.001^{* * *} *$

(0.003)

$-0.001 *$

(0.003)

0.001

(0.002)

0.003

(0.008)

0.001 *

(0.001)

$-0.001$

(0.001)

-2.100 ***

(0.481)

0.001

(0.009)

$0.007 * * *$

(0.001)

$-0.004$

(0.003)

$-0.056$

(0.064)

Yes

Yes

171

0.509

0.000
Not Well-

capitalized

banks

(3)
$-0.001$

(0.008)

$-0.003$

(0.003)

$-0.002$

(0.001)

0.007

(0.003)

$-0.003$

(0.008)

$0.004^{* *}$

(0.001)

$-0.001 * * *$

(0.004)

$-1.463^{* * *} *$

(0.426)

$-0.004 * * *$

(0.009)

0.001

(0.006)

$0.011^{* * * *}$

(0.001)

$-0.191 * * *$

(0.040)

Yes

Yes

171

0.270

0.000

The table presents the results of the cross-sectional analyses conducted to test hypothesis $2(\mathrm{H} 2)$. The dependent variable is the average of the cumulative abnormal returns (CARs) among a three-days event window $(-1 ;+1)$ obtained through the conduction of the event study. The key explanatory variables are the regulatory capital ratio (Tier1) for the bank capital adequacy; liquid assets over total assets (LiquidAss_TA), loans over total assets (Loans_TA), loan loss provisions over total loans (LLP_Tloans) and non-performing loans over total assets $\left(\boldsymbol{N P L} \_\boldsymbol{T A}\right)$ for the bank asset quality; the risk weighted assets (RWAs) for the bank solvency. The control variables include two agency cost variables, such as the dividend pay-out (Dividend Payout) and the risk-taking (Risk-taking), and other variables like the GDP growth rate $(\% \Delta G D P)$, book leverage (Leverage) and size (Size). The first column reports the OLS estimations referred to the full sample of European banks, while the second column refers to the well-capitalized banks (which the regulatory capital ratio - Tier1-is above the third quartile (75p) when the median of the ratio is 17\%) and the third column refers to the not well-capitalized banks (which the regulatory capital ratio-Tier1-is lower of the first quartile (25p) when the median of the ratio is $17 \%$ ). 
Table 9 (continued)

All the regressions 1) have standard errors (reported in parentheses) that are corrected for clustering at the firm level; 2) are heteroskedasticity robust and 3) include year (Year_FE) and country (Country_FE) fixed effects. Reported values: coefficient (p-value) (***) (**) (*) indicate significance levels at $1 \%,(5 \%)$ (10\%), two tailed. See "Appendix 2" for variable definitions. The regressions are based on the following model (Eq. 4):

Table 10 Robustness tests on the event study with alternative specifications

\begin{tabular}{llcccc}
\hline Nr. Event & Date & Count & $\begin{array}{c}\text { CARs } \\
(-1,+1)\end{array}$ & $\begin{array}{l}\text { CARs } \\
(-2,+2)\end{array}$ & $\begin{array}{l}\text { CARs } \\
(-1,+3)\end{array}$ \\
\hline Event_1 & January 22nd, 2015 & 117 & 0.002 & 0.006 & 0.002 \\
& & & $(0.002)$ & $(0.003)$ & $(0.002)$ \\
Event_2 & March 3rd, 2015 & 117 & 0.0001 & -0.007 & $-0.017 * *$ \\
& & & $(0.003)$ & $(0.005)$ & $(0.006)$ \\
Event_3 & April 15th,2015 & 117 & $-0.011^{*}$ & $-0.037 * *$ & $-0.049 * * *$ \\
& & & $(0.005)$ & $(0.011)$ & $(0.013)$ \\
Event_4 & March 10th, 2016 & 120 & $-0.028^{* * *}$ & $-0.078^{* * *}$ & $-0.080^{* * *}$ \\
& & & $(0.006)$ & $(0.011)$ & $(0.013)$ \\
Event_5 & April 21st, 2016 & 120 & -0.009 & $-0.066^{* * *}$ & $-0.073 * * *$ \\
& & & $(0.007)$ & $(0.012)$ & $(0.012)$ \\
Event_6 & July 22nd, 2016 & \multirow{2}{*}{120} & -0.013 & $-0.086^{* * *}$ & $-0.094 * *$ \\
& & & 0.008 & $(0.011)$ & $(0.013)$ \\
\hline
\end{tabular}

This table presents the results of the market reaction estimation following the methodology of a standard market model (Mackinlay, 1997; Petrella \& Resti, 2013; Ricci, 2015) for testing the first hypothesis in an alternative way and computing the cumulative abnormal returns (CARs). We replace the Eq. 1 (Eq. 1) with Eq. 5 (Eq. 5) for computing the returns $\left(\boldsymbol{R}_{i t}\right)$, while the second model (Eq. 2) to compute the abnormal returns $\left(\boldsymbol{A} \boldsymbol{R}_{i t}\right)$ and the third model (Eq. 3) to compute the cumulative abnormal returns $(\boldsymbol{C A R \boldsymbol { R }}$

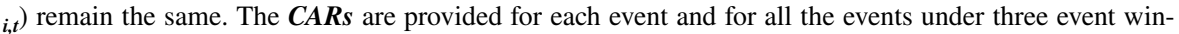
dows identification composed by three or five days including the day of the announcement: $(-1 ;+1)$, $(-2 ;+2)$ and $(-1 ;+3)$. Reported values: coefficient (p-value) $(* * *)(* *)(*)$ indicate significance levels at $1 \%,(5 \%)(10 \%)$. Clustered standard errors are given in parentheses. The computation of the returns is based on the following model (Eqs. 2, 5):

Table 12 (Panel B) presents the results of the component analyses related to the liability side of the European banks' balance sheets, because the new QE liquidity conditions may affect also the deposits and other sources of debt financing (Acharya \& Ryan, 2016; Laux \& Rauter, 2017). The dependent variable is the cumulative abnormal returns $(C A R s)$ among a three-days event window $(-1 ;+1)$, while the explanatory variables are the main drivers of the liability side of the banks' balance sheets, such as the deposits over total liabilities (Deposits_TL), the short-term funding and debt securities over total liabilities (ShortTermFund\&DebtSec_TL) and the subordinated debt over total liabilities (Subordinated debt_TL). The regressions include as control variables Dividend Pay-out, Risk-taking, \% $\triangle$ GDP, Book leverage, and Size and the year (Year_FE) and country (Country_FE) fixed effects. The first column reports the OLS estimations referred to the full sample of European banks, 
while the second column is referred to the well-capitalized banks and the third column is referred to the not well-capitalized banks. The regressions are based on the following model:

$$
\text { CARs }_{i, t}=\beta_{0}+\beta_{1} \text { Banks' liability components }_{i, t}+\text { Controls }+ \text { Year_FE }+ \text { Country_FE }+\varepsilon_{i, t}
$$

In this case, the findings show just a positive and significant association between CARs and the Subordinated debt_TL $\left(0.775^{* * *}\right)$, when we consider the subsample of well capitalized banks.

Finally, we perform another additional test considering the sample of banks joining the comprehensive assessment, such as the major milestone towards the operational start of the Single Supervisory Mechanism (SSM) in November 2014 (Table 13). The comprehensive assessment was announced on October 23rd, 2013 taking effect on November $20136 \mathrm{~F}^{7}$ One of the goals of this exercise is to enhance transparency by improving the quality of information available on the condition of the banks (Bischof \& Daske, 2013). We split the sample of the European banks in two subsamples based on the parameter of the Marginal Expected Shortfall (MES) around a threshold of 5\%. We identify $M E S$ as the difference between a given bank's TIER 1 capital under Basel II and the announced implementation of Basel III. The dependent variable is the cumulative abnormal returns (CARs) among a three-days event window $(-1 ;+1)$ obtained through the conduction of the event study. The key explanatory variables are the regulatory capital ratio Tierl for the bank capital adequacy; liquid assets over total assets (LiquidAss_TA), loans over total assets (Loans_ $T A$ ), loan loss provisions over total loans (LLP_Tloans) for the bank asset quality; the risk weighted assets (RWAs) for the bank solvency. The control variables include two agency cost variables, such as the dividend pay-out (Dividend Payout) and the risk-taking (Risk-taking), and other variables like the GDP growth rate (\% $\Delta G D P)$, book leverage (Leverage) and size (Size). The regressions are based on the model reported in (Eq. 4) including the year (Year_FE) and country (Country_FE) fixed effects.

Table 13 reports the results, where in the case of banks with MES $<5 \%$ there is a positive and significant association between CARs and the Tierl $\left(0.004^{* * *}\right)$ and a negative and significant association between CARs and LiquidAss_TA $\left(-0.001^{* *}\right)$ and Loans_TA $\left(-0.056^{*}\right)$. These findings are consistent with the first one reported in the Table 9, where again the most financially robust banks would benefit of the new liquidity injection provided by ECB QE.

\section{Conclusion}

This study investigates whether (exogenous) liquidity injection affects banks' valuation. Liquidity is crucial to the financial soundness of banks and to ensure a functioning lending channel, thus we exploit investors' reactions to the announcements of the Quantitative Easing program as a shock of new liquidity provisions on a sample of

\footnotetext{
${ }^{7}$ https://www.ecb.europa.eu/press/pr/date/2013/html/pr131023.en.html
} 
Table 11 Results of additional tests-Bank balance sheet components' analyses: Panel A The table presents the results of the component analyses related to the asset side of the European banks' balance sheets

$$
\text { CARs }(-1,+1)
$$

\begin{tabular}{lll}
\hline Full sample & Well-capitalized banks & $\begin{array}{l}\text { Not well- } \\
\text { capitalized } \\
\text { banks }\end{array}$
\end{tabular}

(2)

\begin{tabular}{|c|c|c|c|}
\hline \multirow[t]{2}{*}{ Mortgage loans_TA } & $-0.042 * * *$ & -0.008 & $-0.062 * * *$ \\
\hline & $(0.001)$ & $(0.009)$ & $(0.004)$ \\
\hline \multirow[t]{2}{*}{ Consumerloans_TA } & -0.009 & 0.010 & -0.019 \\
\hline & $(0.002)$ & $(0.011)$ & $(0.008)$ \\
\hline \multirow[t]{2}{*}{ Corporate loans_TA } & $-0.044 * * *$ & 0.027 & $-0.051^{*}$ \\
\hline & $(0.004)$ & $(0.011)$ & $(0.010)$ \\
\hline \multirow[t]{2}{*}{ Securities_TA } & $-0.377^{*}$ & -0.016 & -0.429 \\
\hline & $(0.005)$ & $(0.021)$ & $(0.012)$ \\
\hline \multirow[t]{2}{*}{ FixedAss_TA } & 0.532 & 0.501 & 0.768 \\
\hline & $(0.258)$ & $(0.331)$ & $(0.321)$ \\
\hline \multirow[t]{2}{*}{ Dividend Payout } & $-0.008^{*}$ & -0.001 & $-0.001^{*}$ \\
\hline & $(0.001)$ & $(0.001)$ & $(0.001)$ \\
\hline \multirow[t]{2}{*}{ Risk-taking } & $-1.028 * * *$ & $-1.641 * * *$ & $-0.919^{*}$ \\
\hline & $(0.061)$ & $(0.022)$ & $(0.206)$ \\
\hline \multirow[t]{2}{*}{$\% \Delta G D P$} & $-0.003^{*}$ & $-0.007 *$ & $-0.003^{* *}$ \\
\hline & $(0.001)$ & $(0.002)$ & $(0.001)$ \\
\hline \multirow[t]{2}{*}{ Leverage } & 0.001 & 0.004 & -0.001 \\
\hline & $(0.003)$ & $(0.001)$ & $(0.003)$ \\
\hline \multirow[t]{2}{*}{ Size } & $0.008 * * *$ & -0.004 & $0.010 *$ \\
\hline & $(0.003)$ & $(0.002)$ & $(0.001)$ \\
\hline \multirow[t]{2}{*}{ Constant } & $-0.154^{* * *}$ & -0.008 & $-0.175^{*}$ \\
\hline & $(0.001)$ & $(0.025)$ & $(0.018)$ \\
\hline Year_FE & Yes & Yes & Yes \\
\hline Country_FE & Yes & Yes & Yes \\
\hline Observations & 711 & 171 & 171 \\
\hline$R$-squared & 0.331 & 0.362 & 0.389 \\
\hline Prob $>F$ & 0.000 & 0.000 & 0.000 \\
\hline
\end{tabular}

Here, this is to exploit banks' heterogeneity, taking into account specific components of banks' balance sheets according to the level of banks' capitalization (Laux \& Rauter, 2017). The dependent variable is the average of the cumulative abnormal returns $(\boldsymbol{C A R \boldsymbol { s } )}$ among a three-days event window $(-1 ;+1)$ obtained through carrying out the event study. The explanatory variables are the main drivers of the asset side of the banks' balance sheets, such as the mortgage loans (Mortgage loans_TA), the consumer loans (Consumer loans_TA), the corporate loans (Corporate loans_TA), the securities assets (Securities_TA) and the fixed assets (FixedAss_TA). As control variables we include the GDP growth rate (\% $\boldsymbol{\Delta} \boldsymbol{\Delta G D P})$, book leverage (Leverage) and size (Size). The first column reports the OLS estimations referred to the full sample of European banks, while the second column refers to the well-capitalized banks (which the regulatory capital ratio - Tier1-is above the third quartile (75p) when the median of the ratio is $17 \%$ ) and the third column refers to the not well-capitalized banks (which the regulatory capital ratio - Tier1-is lower of the first quartile (25p) when the median of the ratio is $17 \%$ ). All the regressions 1) have standard errors (reported in parentheses) that are corrected for clustering at the firm level; 2) 
Table 11 (continued)

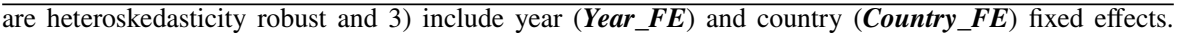
Reported values: coefficient (p-value) $(* * *)(* *)(*)$ indicate significance levels at 1\%, (5\%) (10\%), two tailed. See "Appendix 2" for variable definitions. The regressions are based on the following model (Eq. 6)

European banks. Furthermore, we condition the strength of the market reactions on a series of bank-level attributes that may meaningfully affect ways in which according to specific bank characteristics (capital adequacy, asset quality and risk exposure).

In order to address our questions, we look at a number of key events leading to the passage of QE among the years 2015-2016 and we exploit at firm-level whether investors envisage any potential benefits due to the liquidity provision of the ECB. Our findings report a negative overall bank stock price reaction among the six QE announcements, thus indicating a slight investors' concerns about the exogenous liquidity flowing through an extraordinary intervention by the ECB. Next, we look at bank-level characteristics as potential drivers of the market reactions: consistent with our expectations, we find that the pre-exiting conditions faced by banks prior to the QE announcements significantly shape investors' reactions. Splitting the sample between well or not well-capitalized banks; the findings show that not well-capitalized banks would possibly not receive any benefits in terms of economic and financial robustness. Banks experiencing higher financial stability in the period just prior to the launch of the QE programme would allow banks to address the new liquidity for becoming stronger and more aligned to the regulatory ratios.

Our study is subject to a number of caveats and limitations. First, similar to the most part of event studies, we assume the hypothesis of market efficiency, where the market adjusts rapidly to new information (Fama et al., 1969). Second, we lack data about the exact amount and timing of the purchases of assets by ECB; the Central Bank does not disclose information about the timing and the amount of bonds relieved from the banks' portfolios during the QE programme. Finally, because the results provide an estimate of the investors' assessments regarding the few trust on European banks given the QE programme, it is also evident that the range of time period regarding banks' accounting data are restricted to a short period of 2 years (2014-2015), thus not providing a comprehensive evaluation of these outcomes.

The empirical evidence resulting from our tests allow identifying potential implications for the regulator aiming to guarantee financial stability within the banking sector, especially to avoid large and systemic bank failure. In this regard, the on-going consolidation moment in the banking industry creates an increasing number of large banks. One policy response to the potential for "too-big-to-fail" dangers is to combine high regime of regulation with intervention of central banks as a safety net.

In conclusion, by combining banks-level information with the expectations of new liquidity injection we offer new insights: first, undercapitalized banks could not benefit of new liquidity provided by ECB to support the real sector, whilst the well-capitalized banks could reactivate effectively the lending activity. This is an important takeaway as it shows that — due to the current regulatory framework-only banks with sound bank capital are able to exploit liquidity—suggesting that a blanket intervention may not 
Table 12 Results of additional tests-Bank balance sheet components' analyses: Panel B The table presents the results of the component analyses related to the liability side of the European banks' balance sheets

$\operatorname{CARs}(-1,+1)$

\begin{tabular}{lll}
\hline Full Sample & Well-capitalized banks & $\begin{array}{l}\text { Not Well- } \\
\text { capitalized } \\
\text { banks }\end{array}$ \\
&
\end{tabular}

(1)

\begin{tabular}{|c|c|c|c|}
\hline \multirow[t]{2}{*}{ Deposits_TL } & 0.011 & 0.022 & 0.019 \\
\hline & $(0.004)$ & $(0.014)$ & $(0.008)$ \\
\hline \multirow[t]{2}{*}{ ShortTermFund\&DebtSec_TL } & -0.014 & 0.087 & -0.105 \\
\hline & $(0.018)$ & $(0.039)$ & $(0.040)$ \\
\hline \multirow[t]{2}{*}{ Subordinated debt_TL } & -0.239 & $0.775^{* * *}$ & -0.572 \\
\hline & $(0.068)$ & $(0.073)$ & $(0.206)$ \\
\hline \multirow[t]{2}{*}{ Dividend Payout } & $-0.001 * *$ & -0.001 & $-0.001 * *$ \\
\hline & $(0.002)$ & $(0.007)$ & $(0.002)$ \\
\hline \multirow[t]{2}{*}{ Risk-taking } & -1.349 & $-1.426^{* * * *}$ & $-1.419 * * *$ \\
\hline & $(0.033)$ & $(0.048)$ & $(0.086)$ \\
\hline \multirow[t]{2}{*}{$\% \Delta G D P$} & $-0.004 *$ & $0.006^{*}$ & $-0.005^{* *}$ \\
\hline & $(0.011)$ & $(0.003)$ & $(0.001)$ \\
\hline \multirow[t]{2}{*}{ Leverage } & -0.001 & 0.003 & -0.002 \\
\hline & $(0.003)$ & $(0.001)$ & $(0.001)$ \\
\hline \multirow[t]{2}{*}{ Size } & $-0.009 * *$ & -0.002 & $-0.012 * *$ \\
\hline & $(0.001)$ & $(0.001)$ & $(0.002)$ \\
\hline \multirow[t]{2}{*}{ Constant } & -0.188 & -0.066 & $-0.238^{*}$ \\
\hline & $(0.018)$ & $(0.026)$ & $(0.040)$ \\
\hline Year_FE & Yes & Yes & Yes \\
\hline Country_FE & Yes & Yes & Yes \\
\hline Observations & 711 & 171 & 171 \\
\hline$R$-squared & 0.273 & 0.391 & 0.331 \\
\hline Prob $>F$ & 0.000 & 0.000 & 0.000 \\
\hline
\end{tabular}

This is to exploit banks' heterogeneity, taking into account specific components of banks' balance sheets according to the level of banks' capitalization (Laux \& Rauter, 2017). The dependent variable is the cumulative abnormal returns $(\boldsymbol{C A R s})$ among a three-days event window $(-1 ;+1)$ obtained through carrying out the event study. The explanatory variables are the main drivers of the liability side of the banks' balance sheets, such as the deposits over total liabilities (Deposits_TL), the short-term funding and debt securities over total liabilities (ShortTermFund\&DebtSec_TL) and the subordinated debt over total liabilities (Subordinated debt_TL). As control variables we include the GDP growth rate $(\% \Delta G D P)$, book leverage (Leverage) and size (Size). The first column reports the OLS estimations refers to the full sample of European banks, while the second column refers to the well-capitalized banks (which the regulatory capital ratio-Tier1-is above the third quartile $(75 p)$ when the median of the ratio is $17 \%$ ) and the third column refers to the not well-capitalized banks (which the regulatory capital ratio-Tier1-is lower of the first quartile (25p) when the median of the ratio is $17 \%$ ). All the regressions 1) have standard errors (reported in parentheses) that are corrected for clustering at the firm level; 2) are heteroskedasticity robust and 3) include year $($ Year_FE) and country (Country_FE) fixed effects. Reported values: coefficient (p-value) (***) $(* *)(*)$ indicate significance levels at 1\%, (5\%) (10\%), two tailed. See "Appendix 2" for variable definitions. The regressions are based on the following model (Eq. 7) 
Table 13 Results of additional tests-Sample split on Basel III Tier 1 shortfall

$$
\text { CARs }(-1,+1)
$$

MES $<5 \%$ Banks

MES $>5 \%$ Banks

(1)

(2)

\begin{tabular}{|c|c|c|}
\hline Tier1 & $\begin{array}{l}0.004 * * * \\
(0.001)\end{array}$ & $\begin{array}{l}-0.003 \\
(0.001)\end{array}$ \\
\hline LiquidAss_TA & $\begin{array}{l}-0.001 * * \\
(0.004)\end{array}$ & $\begin{array}{l}-0.001 \\
(0.004)\end{array}$ \\
\hline Loans_TA & $\begin{array}{l}-0.056^{* *} \\
(0.002)\end{array}$ & $\begin{array}{l}-0.004 \\
(0.002)\end{array}$ \\
\hline LLP_Tloans & $\begin{array}{l}0.005^{*} \\
(0.001)\end{array}$ & $\begin{array}{l}0.004 \\
(0.002)\end{array}$ \\
\hline$N P L \_T A$ & $\begin{array}{l}-0.003 \\
(0.004)\end{array}$ & $\begin{array}{l}-0.001 \\
(0.009)\end{array}$ \\
\hline$R W A s$ & $\begin{array}{l}0.001 \\
(0.001)\end{array}$ & $\begin{array}{l}-0.001 \\
(0.001)\end{array}$ \\
\hline Dividend Payout & $\begin{array}{l}-0.001 \\
(0.001)\end{array}$ & $\begin{array}{l}-0.008 \\
(0.004)\end{array}$ \\
\hline Risk-taking & $\begin{array}{l}-1.546^{* * * *} \\
(0.130)\end{array}$ & $\begin{array}{l}-2.182^{* * *} \\
(0.131)\end{array}$ \\
\hline$\% \Delta G D P$ & $\begin{array}{l}-0.004^{*} \\
(0.001)\end{array}$ & $\begin{array}{l}0.008 * * \\
(0.003)\end{array}$ \\
\hline Leverage & $\begin{array}{l}0.008 \\
(0.001)\end{array}$ & $\begin{array}{l}0.008 \\
(0.001)\end{array}$ \\
\hline Size & $\begin{array}{l}0.010 * * \\
(0.001)\end{array}$ & $\begin{array}{l}-0.006^{* * *} \\
(0.001)\end{array}$ \\
\hline Constant & $\begin{array}{l}-0.182 * * \\
(0.008)\end{array}$ & $\begin{array}{l}-0.052 * * \\
(0.009)\end{array}$ \\
\hline Year_FE & Yes & Yes \\
\hline Country_FE & Yes & Yes \\
\hline Observations & 167 & 544 \\
\hline$R$-squared & 0.337 & 0.514 \\
\hline Prob $>F$ & 0.000 & 0.000 \\
\hline
\end{tabular}

This table reports the estimation results of a further test based on a sample of the European banks joining the comprehensive assessment of the Single Supervisory Mechanism (SSM) started in November 2014. We split the sample of the European banks in two subsamples based on the parameter of the Marginal Expected Shortfall $(\boldsymbol{M E S})$ around a threshold of 5\%. We identify $M E S$ as the difference between a given bank's TIER 1 capital under Basel II and the announced implementation of Basel III. The dependent variable is the average of the cumulative abnormal returns (CARs) among a three-days event window $(-1 ;+1)$ obtained through carrying outthe event study. The key explanatory variables are the regulatory capital ratio (Tier1) for the bank capital adequacy; liquid assets over total assets (LiquidAss_TA), loans over total assets (Loans_TA), loan loss provisions over total loans (LLP_Tloans) and non-performing loans over total assets (NPL_TA) for the bank asset quality; the 
Table 13 (continued)

risk weighted assets (RWAs) for the bank solvency. The control variables include two agency cost variables, such as the dividend pay-out (Dividend Payout) and the risk-taking (Risk-taking), and other variables like the GDP growth rate $(\% \Delta G D P)$, book leverage (Leverage) and size (Size). All the regressions (1) have standard errors (reported in parentheses) that are corrected for clustering at the firm level; (2) are heteroskedasticity robust and (3) include year $($ Year_FE) and country (Country_FE) fixed effects. Reported values: coefficient (p-value) $(* * *)(* *)(*)$ indicate significance levels at $1 \%,(5 \%)(10 \%)$, two tailed. See "Appendix 2 " for variable definitions. The regressions are based on the following model: $C A R s_{i, t}=$ $\beta_{0}+\beta_{1}$ Capital Adequacy $_{i, t}+\beta_{2}$ Asset Quality ${ }_{i, t}+\beta_{3}$ Risk Exposure ${ }_{i, t}+$ Year_FE + Country_FE + Controls $+\varepsilon_{i, t}$

be fully effective. In other words, a funding liquidity shock as the Quantitative Easing adopted in the Euro zone can represent a benefit depending on the economic and financial structure of a bank (Zingales, 2009).

\section{Appendix}

\section{Appendix 1: Description of the event study}

Panel A: This figure reports the timeline of the announcements of the Quantitative Easing program related to the decision of new liquidity injection affecting all the banks of the Euro zone. We identify six announcements covering a time period of two years (2015-2016). We use these day-events to identify the estimation windows and the event windows and to compute the cumulative abnormal returns (CARs) following the Fama-French three factor model. The announcements of the European Central Bank related to the QE program provide information (first and third events), details (second and fifth events) and implementations (fourth and sixth events) for describing the mechanism of the new liquidity injection among the European banking sector.

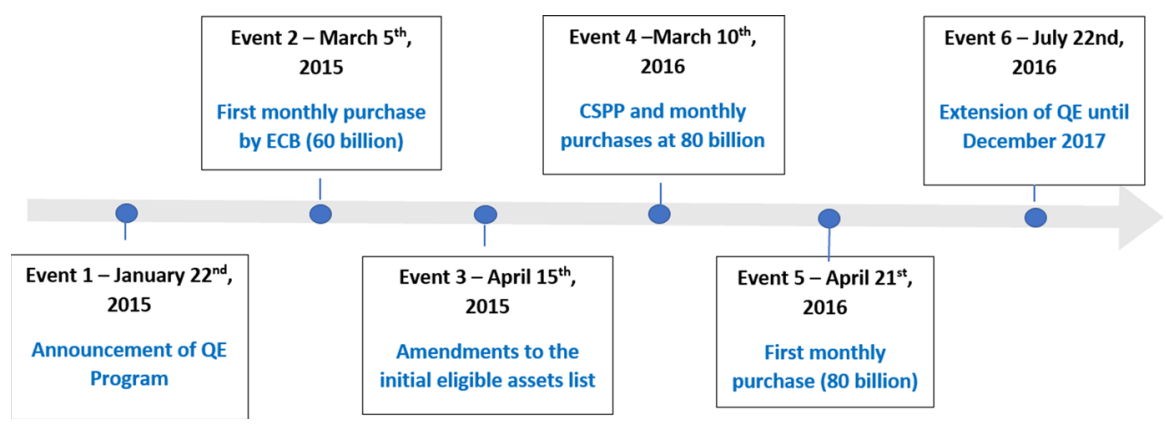


Panel B: This figure presents the timeline for showing the identification of estimation windows and event windows. For the estimation periods we identify two windows $(-30,-5)$ and $(-60,-5)$. We use the first estimation window $(-30,-5)$, when two announcements are close to each other, otherwise we consider the second estimation window $(-60,-5)$. We adopt this approach to avoid any overlapping and cofounding events in order to correctly compute the returns. Furthermore, we identify three event-windows composed by three or five days including the day of the announcement: $(-1 ;+1),(-2 ;+2)$ and $(-1 ;+3)$. We obtain the cumulative abnormal returns around each event following three steps according to the Fama-French three factor model methodology: (1) we use the first model (Eq. 1) to compute the returns $\left(\boldsymbol{R}_{i t}\right)$, (2) the second model (Eq. 2) to compute the abnormal returns $\left(\boldsymbol{A} \boldsymbol{R}_{i t}\right)$ and finally (3) the third model (Eq. 3) to compute the cumulative abnormal returns $\left(\boldsymbol{C A R} \boldsymbol{s}_{i, t}\right)$. The model measures the raw returns on firm's stock, the market returns, the small-minus-big market capitalization portfolio returns $(\boldsymbol{S M B})$, and the high-minus-low book equity/market equity portfolio returns $(\boldsymbol{H} \boldsymbol{M L})$. Given that we considered the European banks' stock prices, we used the Eurostoxx Value, Eurostoxx Growth, Eurostoxx Small and Eurostoxx Large indexes to build Fama and French (1992) size and growth daily factor returns in the Euro Area. The cumulative abnormal returns (CARs) are computed for the six event windows including the six announcements $(\mathrm{t}=0)$. The standardized cross-sectional test by Boehmer, Musumeci, and Poulsen (1991) as modified in Kolari and Pynnönen (2010) is used for statistical inference. The advantage of Boehmer, Musumeci, and Poulsen's standardized cross-sectional t-statistic over other standardized t-tests is that it adjusts for changes in stock return volatility around the event announcements (see Harrington \& Shrider, 2007). Beginning with this t-statistic, in recent work, Kolari and Pynnönen develop an adjusted t-test that additionally considers the cross-sectional correlation when event days are clustered. Since all banks in the sample are affected by at least one of the six common event announcements in our analyses, this new test adjusts for potential dependence between abnormal returns. We also test the number of CARs using the generalized sign Z-test. This test is based on a normal approximation to the binomial distribution and tests the null hypothesis that the fraction of returns is the same in the event window and estimation period (Eqs. 1, 2, 3 ).

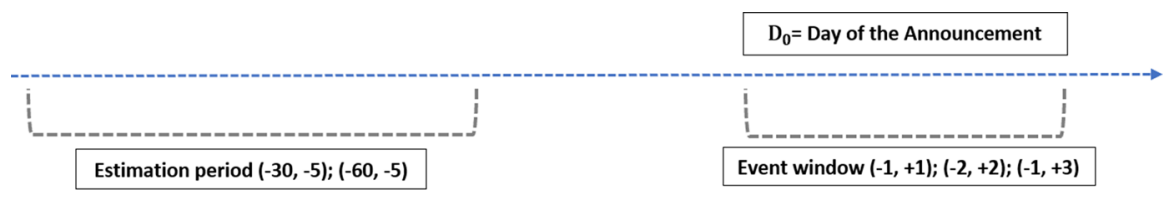


Panel C: This table reports the detailed description for each event considered in the development of the event study. For each event we report also the reference of ECB website's pages.

\begin{tabular}{lll}
\hline Date & Event nr & Description \\
\hline Year 2015 & & \\
\hline January 22nd 2015 & Event_1 & QE program is announced on January 22nd, 2015. It is based on three \\
& actions: (1) the Public Sector Purchase Program (PSPP); (2) the \\
& Asset Backed Securities Purchase Program (ABSPP); (3) the Cov- \\
& ered Bonds Purchase Program (CBPP). The PSPP, the ABSPP, the \\
& CBPP and the CSPP compose the Assets Purchase Program (APP), \\
& commonly better known under the name of Quantitative Easing. Fol- \\
& lowing PSPP, ECB buys from the secondary market the government \\
& bonds of Eurozone countries mainly hold by commercial banks. ECB \\
& buys also bonds holding by agencies and supranationals. The QE is \\
& the most important monetary policy intervention adopted for the first \\
& time by ECB, never experienced before in Euro zone \\
& Source: https://www.ecb.europa.eu/press/pressconf/2015/html/is150 \\
& 122.en.html
\end{tabular}

March 5th 2015 Event_2 QE program initializes on March 5th, 2015. This program consists of purchasing assets for a monthly amount corresponding to $€ 60$ billion. The Euro system buys the same percentage of all the bonds available based on two constraints (maturity between 2 and $31 \mathrm{Y}$, yield above depo rate). The purchases under the program, which amount to $€ 60$ billion per month are intended to carry out until March 2017, or better until, if necessary, a sustained adjustment is seen in the path of inflation consistent with the aim of achieving inflation rates below, but close to, $2 \%$ over the medium term. Source: https://www.ecb.europa. eu/press/pressconf/2015/html/is150305.en.html

April 15th 2015 Event_3 ECB approves amendments to the initial list of agencies located in the Euro area issuing securities that are eligible for the PSPP. The list is available on the ECB's website: https://www.ecb.europa.eu/mopo/ implement/omt/html/pspp.en.html

Year 2016

March 10th 2016 Event_4 ECB announces CSPP (Not banking corporate bonds); an increase of APP monthly purchases corresponding to $€ 80$ billion; TLTRO II with a maturity of 4 years. Given the extension of the APP until March 2017 and the increase in the monthly purchase pace to EUR 80 bn, some further NCBs are now expected to participate in substitute purchases. If these substitute purchases comprise marketable debt instruments issued by international or supranational institutions located in the euro area, such purchases will be subsumed under the 10\% allocation for these securities in the PSPP (from March 2015 until March 2016 this figure was 12\%). The remaining purchases of marketable debt instruments issued by international or supranational institutions located in the euro area will be conducted on behalf of the Euro system by the Banco de España and the Banque de France

Source: https://www.ecb.europa.eu/press/pr/date/2016/html/pr160310. en.html 


\begin{tabular}{|c|c|c|}
\hline Date & Event nr & Description \\
\hline April 21st 2016 & Event_5 & $\begin{array}{l}\text { First monthly assets purchase of } € 80 \text { billion in APP. Furthermore, The } \\
\text { Euro system starts to buy corporate sector bonds under the corporate } \\
\text { sector purchase program (CSPP) on } 8 \text { June } 2016 \text {. The measure helps } \\
\text { to further strengthen the pass-through of the Euro system's asset pur- } \\
\text { chases to financing conditions of the real economy, and, in conjunc- } \\
\text { tion with the other non-standard monetary policy measures in place, } \\
\text { provides further monetary policy accommodation } \\
\text { Source: https://www.ecb.europa.eu/press/pr/date/2016/html/pr160421. } \\
\text { en.html }\end{array}$ \\
\hline July 22nd 2016 & Event_6 & $\begin{array}{l}\text { The APP (or QE)is intended to be carried out until the end of } 2017 \text { and } \\
\text { in any case until the Governing Council oversees a sustained adjust- } \\
\text { ment in the path of inflation that is consistent with its aim of achiev- } \\
\text { ing inflation rates below, but close to, } 2 \% \text { over the medium term. } \\
\text { The APP is part of a package of measures that also includes targeted } \\
\text { longer-term refinancing operations. Source: https://www.ecb.europa. } \\
\text { eu/press/pr/date/2016/html/pr160721.en.html }\end{array}$ \\
\hline
\end{tabular}

\section{Appendix 2}

Panel A: Variable definitions

\begin{tabular}{|c|c|c|}
\hline Variable & Definition & Source \\
\hline \multicolumn{3}{|l|}{ Dependent variable } \\
\hline$C A R s$ & $\begin{array}{l}\text { Cumulative abnormal returns based on Fama- } \\
\text { French } 3 \text { factor model where the Bank stock price } \\
\text { is the daily stock price of the listed European } \\
\text { banks, the Market value and the Book value of } \\
\text { equity for each listed European bank, the Market } \\
\text { stock price is the daily market stock price of the } \\
\text { following market indexes: Stoxx Europe } 600\end{array}$ & $\begin{array}{l}\text { Datastream } \\
\text { Eikon } \\
\text { Thomson Reuters }\end{array}$ \\
\hline Independent variables & & Orbis \\
\hline Tier1 & Tier 1 capital ratio & Bank Focus \\
\hline LiquidAss_TA & Liquid assets divided by total assets & \\
\hline Loans_TA & Total loans over total assets & \\
\hline LLP_Tloans & Loan loss provisioning/total loans & \\
\hline$N P L \_T A$ & Nonperforming loans/total assets & \\
\hline$R W A s \_T A$ & Total risk weighted assets/total assets & \\
\hline Mortgage loans_TA & Mortgage loans/total assets & \\
\hline Consumer loans_TA & Consumer loans/total assets & \\
\hline Corporate loans_TA & Corporate loans/total assets & \\
\hline Securities_TA & $\begin{array}{l}\text { Sum of Available for Sales, Held to Maturity and } \\
\text { trading securities of bank at the end of the year }\end{array}$ & \\
\hline FixedAss_TA & Fixed assets/total assets & \\
\hline Total Assets ( $€$ bn) & Total assets in billions of Euro & \\
\hline Deposits_TL & Total deposits divided by total liabilities & \\
\hline
\end{tabular}




\begin{tabular}{ll}
\hline Variable & Definition \\
\hline ShortTermFund\&DebtSec_TL & $\begin{array}{l}\text { Short term funding and debt securities divided by } \\
\text { total liabilities }\end{array}$ \\
$\begin{array}{l}\text { Subordinated debt_TL } \\
\text { Total Liabilities }(€ \text { bn) }\end{array}$ & Total liabilities in billions of Euro \\
Control variables & (common stock dividends + preferred stock divi- \\
Dividend Pay-out & dends)/net income \\
& Total risk is the average annual standard deviation \\
Risk-taking & of daily stock returns (Minton et al., 2014) \\
\% & Percentage change in GDP per capita (Bushman \& \\
& Williams, 2012) \\
Book leverage & Total assets/total equity (Laux \& Rauter, 2017) \\
Size & Natural logarithm of total assets (Bushman \& Wil- \\
& liams, 2012) \\
\hline
\end{tabular}

Panel B: Market index definitions

\begin{tabular}{|c|c|c|c|}
\hline Variable & $\mathrm{Abb}$ & Definition & Source \\
\hline STOXX Europe 600 & djstoxx & $\begin{array}{l}\text { Derived from the Stoxx Europe Total Market Index (TMI) } \\
\text { and is a subset of the Stoxx Global } 1800 \text { index. With } \\
\text { a fixed number of } 600 \text { components, the Stoxx Europe } \\
600 \text { index represents large, mid and small capitalization } \\
\text { companies across } 18 \text { countries of the European region: } \\
\text { Austria, Belgium, Czech Republic, Denmark, Finland, } \\
\text { France, Germany, Greece, Ireland, Italy, Luxembourg, } \\
\text { the Netherlands, Norway, Portugal, Spain, Sweden, } \\
\text { Switzerland and UK }\end{array}$ & $\begin{array}{l}\text { Datastream } \\
\text { Eikon } \\
\text { Thomson } \\
\text { Reuters }\end{array}$ \\
\hline STOXX Europe 50 & djes50i & $\begin{array}{l}\text { Europe's leading Blue-chip index provides a representation } \\
\text { of super sector leaders in Europe. The index covers } 50 \\
\text { stocks from } 18 \text { European countries: Austria, Belgium, } \\
\text { Czech Republic, Denmark, Finland, France, Germany, } \\
\text { Greece, Ireland, Italy, Luxembourg, the Netherlands, } \\
\text { Norway, Portugal, Spain, Sweden, Switzerland and UK. } \\
\text { This index id licensed to financial institutions to serve as } \\
\text { underlying for a wide range of investment products such } \\
\text { as Exchange traded funds (ETFs), Futures and options } \\
\text { and structured products worldwide }\end{array}$ & \\
\hline$S \& P$ euro & speurop & European stocks index. It is part of the S\&P Global 1200 & \\
\hline Ftse Eurotop 100 & fteu100 & $\begin{array}{l}\text { Designed to measure the performance of companies } \\
\text { resident and incorporated in Europe. The index can be } \\
\text { used for benchmarking purposes and as tools in the crea- } \\
\text { tion of index tracking funds, exchange traded funds and } \\
\text { derivatives. It represents the performance of the } 100 \text { most } \\
\text { highly capitalized blue-chip companies in Europe }\end{array}$ & \\
\hline
\end{tabular}




\begin{tabular}{|c|c|c|c|}
\hline Variable & Abb & Definition & Source \\
\hline Ftse Eurofirst 100 & ftefcle & $\begin{array}{l}\text { The } 60 \text { largest companies ranked by market capitalization } \\
\text { in the FTSE Developed Europe Index and } 40 \text { additional } \\
\text { companies selected for their size and sector represen- } \\
\text { tation. It provides a range of liquid and transparent } \\
\text { pan-European and Eurozone indices, which track equity } \\
\text { performance across the region as a whole and across } 18 \\
\text { industry sectors }\end{array}$ & \\
\hline Ftse Eurofirst 80 & ftef80e & $\begin{array}{l}\text { The } 60 \text { largest companies ranked by market capitalization } \\
\text { in the FTSE Eurozone index and } 20 \text { additional companies } \\
\text { selected for their size and sector representation }\end{array}$ & \\
\hline
\end{tabular}

\section{Appendix 3}

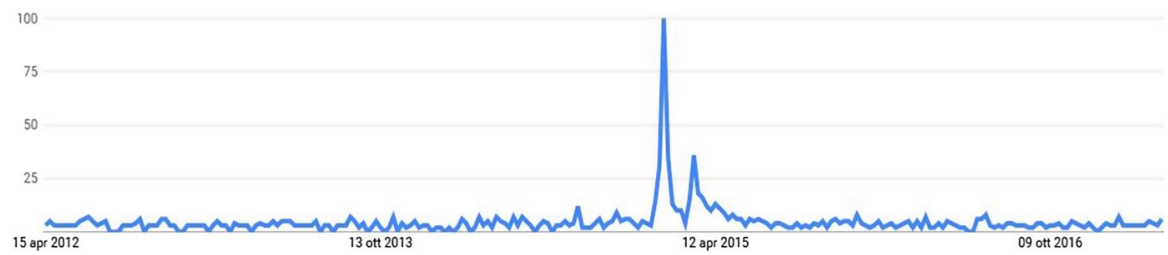

By tracking the number of searches on Google Trends and using the key word ECB $\mathrm{QE}$ the results shows that these announcements were not anticipated by investors in days prior to the actual release.

Acknowledgements Sara Longo gratefully acknowledges comments and suggestions from Wei Wang (discussant), Sudipta Basu, Holger Daske, Xing Huan, Urooj Khan, Juan Manuel Garcia Lara, Shiva Rajgopal, Ornella Ricci, Stephen Ryan, William Rees, Joshua Ronen, Luigi Zingales as well as seminar participants at Swiss Accounting Research Alpine Camp (Champery, 2018), XIV International Accounting Research Symposium (Madrid, 2018), 2nd and 3rd Accounting Summer Camp (Bolzano, 2018-2019), SIDREA (Verona, 2018), University of Padova (2018), University Pompeu Fabra (Barcelona, 2019), SKEMA Business School (Sophia-Antipolis, 2019), 42nd EAA Annual Congress (Cyprus, 2019), AAA Virtual Conference (2020). She gratefully acknowledges the hospitality of Columbia Business School (NYC) while working on this project. All errors are our own.

Funding Open access funding provided by Libera Università di Bolzano within the CRUI-CARE Agreement.

Open Access This article is licensed under a Creative Commons Attribution 4.0 International License, which permits use, sharing, adaptation, distribution and reproduction in any medium or format, as long as you give appropriate credit to the original author(s) and the source, provide a link to the Creative Commons licence, and indicate if changes were made. The images or other third party material in this article are included in the article's Creative Commons licence, unless indicated otherwise in a credit line to the material. If material is not included in the article's Creative Commons licence and your intended use is not permitted by statutory regulation or exceeds the permitted use, you will need to obtain permission directly from the copyright holder. To view a copy of this licence, visit http://creativecommons.org/licen ses/by/4.0/. 


\section{References}

Acharya, V. V., \& Ryan, S. G. (2016). Banks Financial reporting and financial system stability. Journal of Accounting Research, 54(2), 277-340

Acharya, V. V., \& Steffen, S. (2015). The "greatest" carry trade ever? Understanding eurozone bank risks. Journal of Financial Economics, 115(2), 215-236

Agoraki, M.-E.K., Delis, M. D., \& Pasiouras, F. (2011). Regulations, competition and bank risk-taking in transition countries. Journal of Financial Stability, 7(1), 38-48

Ahrens, T., Filatotchev, I., \& Thomsen, S. (2011). The research frontier in corporate governance. Journal of Management \& Governance, 15(3), 311-325

Allen, F., \& Carletti, E. (2008). Mark-to-market accounting and liquidity pricing. Journal of Accounting and Economics, 45(2-3), 358-378

Archer, S., Karim, R. A. A., \& Al-Deehani, T. (1998). Financial contracting, governance structures and the accounting regulation of Islamic banks: An analysis in terms of agency theory and transaction cost economics. Journal of Management and Governance, 2(2), 149-170

Attig, N., El Ghoul, S., Guedhami, O., \& Rizeanu, S. (2013). The governance role of multiple large shareholders: Evidence from the valuation of cash holdings. Journal of Management \& Governance, 17(2), 419-451

Barth, J. R., Caprio, G., \& Levine, R. (2008). Rethinking bank regulation. Cambridge Books.

Beltratti, A., \& Stulz, R. M. (2012). The credit crisis around the globe: Why did some banks perform better? Journal of Financial Economics, 105(1), 1-17

Berger, A. N., \& Bouwman, C. H. (2013). How does capital affect bank performance during financial crises? Journal of Financial Economics, 109(1), 146-176

Berger, A. N., \& Sedunov, J. (2017). Bank liquidity creation and real economic output. Journal of Banking \& Finance, $81,1-19$

Betz, F., Oprică, S., Peltonen, T. A., \& Sarlin, P. (2014). Predicting distress in European banks. Journal of Banking \& Finance, 45, 225-241

Bischof, J., \& Daske, H. (2013). Mandatory disclosure, voluntary disclosure, and stock market liquidity: Evidence from the EU Bank Stress Tests. Journal of Accounting Research, 51(5), 997-1029

Boehmer, E., Masumeci, J., \& Poulsen, A. B. (1991). Event-study methodology under conditions of event-induced variance. Journal of Financial Economics, 30(2), 253-272

Bowen, R. M., \& Khan, U. (2014). Market reactions to policy deliberations on fair value accounting and impairment rules during the financial crisis of 2008-2009. Journal of Accounting and Public Policy, 33(3), 233-259

Boyd, J. H., \& Heitz, A. (2016). The social costs and benefits of too-big-to-fail banks: A "bounding" exercise. Journal of Banking \& Finance, 68, 251-265

Brown, S. J., \& Warner, J. B. (1985). Using daily stock returns: The case of event studies. Journal of Financial Economics, 14(1), 3-31

Brunnermeier, M. K., \& Pedersen, L. H. (2009). Market liquidity and funding liquidity. Review of Financial Studies, 22(6), 2201-2238

Bruno, B., Onali, E., \& Schaeck, K. (2016). Market reaction to bank liquidity regulation. Journal of Financial and Quantitative Analysis (JFQA), 53, 899

Bushman, R. M., Davidson, R. H., Dey, A., \& Smith, A. (2018). Bank CEO materialism: Risk controls, culture and tail risk. Journal of Accounting and Economics, 65(1), 191-220

Bushman, R. M., \& Williams, C. D. (2012). Accounting discretion, loan loss provisioning, and discipline of Banks' risk-taking. Journal of Accounting and Economics, 54(1), 1-18

Bushman, R. M., \& Williams, C. D. (2015). Delayed expected loss recognition and the risk profile of banks. Journal of Accounting Research, 53(3), 511-553

Busta, I., Sinani, E., \& Thomsen, S. (2014). Ownership concentration and market value of European banks. Journal of Management \& Governance, 18(1), 159-183

Calomiris, C. W., \& Khan, U. (2015). An assessment of TARP assistance to financial institutions. Journal of Economic Perspectives, 29(2), 53-80

Calomiris, C. W., Heider, F., \& Hoerova, M. (2015). A theory of bank liquidity requirements. Columbia Business School Research Paper, (14-39).

Chen, R.-R., Yang, T.-H., \& Yeh, S.-K. (2017). The liquidity impact on firm values: The evidence of Taiwan's banking industry. Journal of Banking \& Finance, 82, 191-202 
Cifuentes, R., Ferrucci, G., \& Shin, H. S. (2005). Liquidity risk and contagion. Journal of the European Economic Association, 3(2-3), 556-566

Cornett, M. M., McNutt, J. J., Strahan, P. E., \& Tehranian, H. (2011). Liquidity risk management and credit supply in the financial crisis. Journal of Financial Economics, 101(2), 297-312

Dal Maso, L., Kanagaretnam, K., Lobo, G. J., \& Terzani, S. (2018). The influence of accounting enforcement on earnings quality of banks: Implications of bank regulation and the global financial crisis. Journal of Accounting and Public Policy, 37(5), 402-419

DeAngelo, H., \& Stulz, R. M. (2015). Liquid-claim production, risk management, and bank capital structure: Why high leverage is optimal for banks. Journal of Financial Economics, 116(2), 219-236

de Haan, L., \& van den End, J. W. (2013). Bank liquidity, the maturity ladder, and regulation. Journal of Banking \& Finance, 37(10), 3930-3950

Dewatripont, M., \& Tirole, J. (1993). Efficient governance structure. In C. Mayer \& X. Vives (Eds.), Capital markets and financial intermediation. Cambridge, U.K.: Cambridge University Press.

Diamond, D. W., \& Dybvig, P. H. (1983). Bank runs, deposit insurance and liquidity. Journal of Political Economy, 91(3), 401-419.

Diamond, D. W., \& Rajan, R. G. (2000). A theory of bank capital. The Journal of Finance, 55(6), 2431-2465

Diamond, D. W., \& Rajan, R. G. (2001). Liquidity risk, liquidity creation, and financial fragility: A theory of banking. Journal of Political Economy, 109(2), 287-327

Diamond, D. W., \& Rajan, R. G. (2012). Illiquid banks, financial stability, and interest rate policy. Journal of Political Economy, 120(3), 552-591.

Distinguin, I., Roulet, C., \& Tarazi, A. (2013). Bank regulatory capital and liquidity: Evidence from US and European publicly traded banks. Journal of Banking \& Finance, 37(9), 3295-3317

Fama, E. F. (1991). Efficient capital markets: II. The Journal of Finance, 46(5), 1575-1617

Fama, E. F., Fisher, L., Jensen, M. C., \& Roll, R. (1969). The adjustment of stock prices to new information. International Economic Review, 10(1), 1-21

Fama, E. F., \& French, K. R. (1993). Common risk factors in the returns on stocks and bonds. Journal of Financial Economics, 33, 3-56

Ferri, G., \& Pesic, V. (2017). Bank regulatory arbitrage via risk weighted assets dispersion. Journal of Financial Stability, 33, 331-345

Fiordelisi, F., Galloppo, G., \& Ricci, O. (2014). The effect of monetary policy interventions on interbank markets, equity indices and G-SIFIs during financial crisis. Journal of Financial Stability, 11, 49-61

Flannery, M. J. (1994). Debt maturity and the deadweight cost of leverage: Optimally financing banking firms. The American Economic Review, 84(1), 320-331

Fonseca, A. R., \& Gonzalez, F. (2008). Cross-country determinants of bank income smoothing by managing loan-loss provisions. Journal of Banking \& Finance, 32(2), 217-228

Gao, Y., Liao, S., \& Wang, X. (2018). Capital markets' assessment of the economic impact of the DoddFrank Act on systemically important financial firms. Journal of Banking \& Finance, 86, 204-223

Glaeser, E. L., \& Shleifer, A. (2001). A reason for quantity regulation. American Economic Review, 91(2), 431-435

Gorton, G., \& Pennacchi, G. (1990). Financial intermediaries and liquidity creation. The Journal of Finance, 45(1), 49-71

Gorton, G., \& Winton, A. (2017). Liquidity provision, bank capital, and the macroeconomy. Journal of Money, Credit and Banking, 49(1), 5-37

Gropp, R., \& Heider, F. (2010). The determinants of bank capital structure*. Review of Finance, 14(4), $587-622$

Harrington, S. E., \& Shrider, D. G. (2007). All events induce variance: Analyzing abnormal returns when effects vary across firms. Journal of Financial and Quantitative Analysis, 42, 229-256

Holmström, B., \& Tirole, J. (1998). Private and public supply of liquidity. Journal of Political Economy, 106(1), 1-40

Hong, H., Huang, J.-Z., \& Wu, D. (2014). The information content of Basel III liquidity risk measures. Journal of Financial Stability, 15, 91-111

Imbierowicz, B., \& Rauch, C. (2014). The relationship between liquidity risk and credit risk in banks. Journal of Banking \& Finance, 40, 242-256

Jensen, M. C., \& Meckling, W. H. (1976). Theory of the firm: Managerial behavior, agency costs and ownership structure. Journal of Financial Economics, 3(4), 305-360

Kanagaretnam, K., Lim, C. Y., \& Lobo, G. J. (2011). Effects of national culture on earnings quality of banks. Journal of International Business Studies, 42(6), 853-874 
Kanagaretnam, K., Lim, C. Y., \& Lobo, G. J. (2014). Effects of international institutional factors on earnings quality of banks. Journal of Banking \& Finance, 39, 87-106

Kanagaretnam, K., Lim, C. Y., \& Lobo, G. J. (2014). Influence of national culture on accounting conservatism and risk-taking in the banking industry. The Accounting Review, 89(3), 1115-1149

Kashyap, A. K., \& Stein, J. C. (2000). What do a million observations on banks say about the transmission of monetary policy? American Economic Review, 90(3), 407-428

Khan, U. (2019). Does fair value accounting contribute to systemic risk in the banking industry? Contemporary Accounting Research, 36(4), 2588-2609

Khan, U., Li, B., Rajgopal, S., \& Venkatachalam, M. (2018). Do the FASB's standards add shareholder value? The Accounting Review, 93(2), 209-247

Kim, D., \& Sohn, W. (2017). The effect of bank capital on lending: Does liquidity matter? Journal of Banking \& Finance, 77, 95-107

Kiyotaki, N., \& Moore, J. (1997). Credit cycles. Journal of Political Economy, 105(2), 211-248

Klomp, J., \& de Haan, J. (2012). Banking risk and regulation: Does one size fit all? Journal of Banking \& Finance, 36(12), 3197-3212

Kolari, J. W., \& Pynnönen, S. (2010). Event study testing with cross-sectional correlation of abnormal returns. The Review of Financial Studies, 23(11), 3996-4025

Laeven, L. (2013). Corporate Governance: What's special about banks? Annual Review of Financial Economics, 5(1), 63-92

Lang, M., \& Maffett, M. (2011). Transparency and liquidity uncertainty in crisis periods. Journal of Accounting and Economics, 52(2-3), 101-125

Laux, C., \& Rauter, T. (2017). Procyclicality of U.S. Bank Leverage. Journal of Accounting Research, 55(2), 237-273

MacKinlay, A. C. (1997). Event studies in economics and finance. Journal of Economic Literature, 35(1), 13-39

Madura, J., \& Schnusenberg, O. (2000). Effect of Federal Reserve policies on bank equity returns. Journal of Financial Research, 23(4), 421-447

Memmel, C., \& Raupach, P. (2010). How do banks adjust their capital ratios? Journal of Financial Intermediation, 19(4), 509-528

Minton, B. A., Taillard, J. P., \& Williamson, R. (2014). Financial expertise of the board, risk taking, and performance: Evidence from bank holding companies. Journal of Financial and Quantitative Analysis, 49, 351-380

Myers, S. C., \& Rajan, R. G. (1998). The paradox of liquidity. The Quarterly Journal of Economics, 113(3), 733-771

$\mathrm{Ng}$, J. (2011). The effect of information quality on liquidity risk. Journal of Accounting and Economics, 52(2-3), 126-143

Nielsen, B., \& Smeets, S. (2018). The role of the EU institutions in establishing the banking union. Collaborative leadership in the EMU reform process. Journal of European Public Policy, 25(9), 1233-1256

Petrella, G., \& Resti, A. (2013). Supervisors as information producers: Do stress tests reduce bank opaqueness? Journal of Banking \& Finance, 37(12), 5406-5420

Ratnovski, L. (2009). Bank liquidity regulation and the lender of last resort. Journal of Financial Intermediation, 18(4), 541-558

Ratnovski, L. (2013). Liquidity and transparency in bank risk management. Journal of Financial Intermediation, 22(3), 422-439

Ricci, O. (2015). The impact of monetary policy announcements on the stock price of large European banks during the financial crisis. Journal of Banking \& Finance, 52, 245-255

Rossignolo, A. F., Fethi, M. D., \& Shaban, M. (2013). Market crises and Basel capital requirements: Could Basel III have been different? Evidence from Portugal, Ireland, Greece and Spain (PIGS). Journal of Banking \& Finance, 37(5), 1323-1339

Rösch, C. G., \& Kaserer, C. (2014). Reprint of: Market liquidity in the financial crisis: The role of liquidity commonality and flight-to-quality. Journal of Banking \& Finance, 45, 152-170

Sadka, R. (2011). Liquidity risk and accounting information. Journal of Accounting and Economics, 52(2-3), 144-152

Shleifer, A., \& Vishny, R. W. (1992). Liquidation values and debt capacity: A market equilibrium approach. The Journal of Finance, 47(4), 1343-1366

Stolz, S., \& Wedow, M. (2011). Banks' regulatory capital buffer and the business cycle: Evidence for Germany. Journal of Financial Stability, 7(2), 98-110 
Viale, A. M., Kolari, J. W., \& Fraser, D. R. (2009). Common risk factors in bank stocks. Journal of Banking \& Finance, 33(3), 464-472

Zingales, L. (2009). The future of securities regulation. Journal of Accounting Research, 47(2), 391-425

Publisher's Note Springer Nature remains neutral with regard to jurisdictional claims in published maps and institutional affiliations. 